\title{
DeCEntralizing Family: An InClusive Proposal For INDIVIDUAL TAX FILING IN THE UNITED STATES
}

\author{
Anthony C. Infanti ${ }^{*}$
}

\section{INTRODUCTION}

Our federal tax laws privilege the so-called traditional, nuclear family over all other family arrangements. This privileging is most starkly and easily illustrated by-though in no way confined to-the blatant discrimination against families headed by same-sex couples that permeates our tax laws. ${ }^{1}$ To ameliorate this

* (C) 2010 Anthony C. Infanti, Professor of Law, University of Pittsburgh School of Law. Thanks to Bridget Crawford, Leandra Lederman, Lisa Philipps, Ximena Marinero, and Anne Thibadeau for comments on earlier drafts of this Article. Thanks to the University of Pittsburgh School of Law for providing financial support for the writing of this Article. As always, thanks to Hien for his love and support in everything that I do.

${ }^{1}$ See generally Anthony C. Infanti, Deconstructing the Duty to the Tax System: Unfettering Zealous Advocacy on Behalf of Lesbian and Gay Taxpayers, 61 TAX LAW. 407 (2008); Anthony C. Infanti, Dismembering Families, in CHALlengING Gender INEQUALITY IN TAX POLICY MAKING: COMPARATIVE PERSPECTIVES (Kimberley Brooks et al. eds., forthcoming); Anthony C. Infanti, The Internal Revenue Code as Sodomy Statute, 44 Santa Clara L. Rev. 763 (2004) [hereinafter Infanti, Sodomy Statute]; Anthony C. Infanti, Taxing Civil Rights Gains, 16 MICH. J. GENDER \& L. 319 (2010) [hereinafter Infanti, Taxing Civil Rights Gains].

Recently, a federal district court found the federal Defense of Marriage Act, 1 U.S.C. $\S 7$ (2006), insofar as it applies to the federal tax laws, to violate the right to equal protection of the laws of several married same-sex couples from Massachusetts. Gill v. Office of Pers. Mgmt., 699 F. Supp. 2d 374, 376, 383, 387-98 (D. Mass. 2010). However, because this was not a facial challenge to the statute, it is unclear what the precise impact of this decision will be on the sexual-orientation-based discrimination that permeates our federal tax laws. In any event, as of this writing, it is expected that the federal government will appeal this decision, meaning that the impact of this decision may not be finally determined for several years, if at all. Sandhya Somashekhar, Courts Weighing in on SameSex Marriage; Two Sides Watch for Appeal in Mass. Case, Ruling in California, WASH. PosT, July 10, 2010, at A2.

Even if the decision in Gill were to be upheld on appeal and were applied to all samesex couples who live in states that legally recognize their relationships, this decision would leave out in the cold the many same-sex couples who live in states that refuse legal recognition to their relationships. A different, but equally recent federal district court decision holds greater promise for improving the legal landscape for these couples. In that case, another federal district court held California's Proposition 8, which prohibits samesex couples from marrying in that state, unconstitutional as a violation of the Due Process and Equal Protection Clauses of the U.S. Constitution. Perry v, Schwarzenegger, 704 F. Supp. 2d 921, 991-1004 (N.D. Cal. 2010). The decision in Perry holds the promise of extending the right to marriage to same-sex couples across the country; however, the 
discrimination, recent contributions to the tax literature have proposed establishing variants of a federal domestic partnership regime that would equalize the tax treatment of (1) married different-sex couples and (2) same-sex and unmarried different-sex couples. ${ }^{2}$ Although these proposals do chip away at the hegemony of the traditional family, they do nothing to address the tax treatment of other nontraditional family arrangements. In other words, these proposals accept the privileging of the traditional family in our tax laws, and they attempt only to widen the privileged circle to include certain other relationships patterned after the traditional family norm.

This Article breaks sharply with the approach taken in these recent proposals. Instead of accepting the privileging of the traditional family for tax purposes, it rejects that privileging in favor of a more inclusive approach to determining who is family for tax purposes. The foundation for this approach is a rejection of joint federal income tax filing, which has been the subject of a barrage of criticism from academic commentators in the United States. These criticisms, which are summarized in Part II below, are well taken and, by themselves, certainly provide reason enough to abandon the joint return. However, the joint return is also fundamentally inconsistent with an inclusive approach to determining who is family for tax purposes. Rather than trying to determine whom an individual considers to be part of her family, the joint return works backward by first singling out a certain family arrangement (i.e., the traditional family headed by a married different-sex couple) as the only relevant type of family and then seeking to

court's decision in Perry was appealed on the same day that it was issued, meaning, again, that it may be years before we learn the ultimate outcome of that case. Gay Marriage Appeal Filed, PITTSBURgh Post-GaZeTTE, Aug. 6, 2010 (National Briefs), at A5.

${ }^{2}$ Patricia A. Cain, Taxing Families Fairly, 48 SanTA ClaRA L. ReV. 805, 851-55 (2008); Shari Motro, A New "I Do": Towards a Marriage-Neutral Income Tax, 91 IowA L. REV. 1509, 1543-52 (2006); see also William P. Kratzke, The Defense of Marriage Act (DOMA) Is Bad Income Tax Policy, 35 U. MEM. L. REV. 399, 405-12, 442-45 (2005) (arguing that Congress's refusal to recognize same-sex relationships for federal income tax purposes, including for purposes of filing a joint return, is misguided); Stephanie Hunter McMahon, To Have and to Hold: Rethinking Marital Property and Federal Tax Filing, 11 NEV. L.J. (forthcoming 2011) (manuscript at 62-63) (on file with author) (proposing that same-sex couples in relationships recognized for purposes of state law be required to file joint federal income tax returns); Theodore P. Seto, The Unintended Tax Advantages of Gay Marriage, 65 WASH. \& LEE L. REV. 1529, 1590-92 (2008) (making a proposal similar to those of Cain and Motro to bring the taxation of married different-sex couples and samesex couples into line on the ground that same-sex couples benefit from unwarranted tax advantages due to the refusal of the federal government to recognize same-sex marriagesand not on the ground that same-sex couples encounter discrimination in the application of the tax laws); Keeva Terry, Separate and Still Unequal? Taxing California Registered Domestic Partners, 39 U. ToL. L. REV. 633, 649-52 (2008) (arguing in favor of the creation of a new filing status for same-sex couples covered by community-property laws that would be equivalent to, but separate from, married filing jointly status). 
determine whether an individual's family fits that mold. ${ }^{3}$ A family that does not fit the traditional family mold is not a family for tax purposes and is generally ignored.

Conversely, individual return filing is well-positioned to take into account the diversity of family arrangements in our society because it allows us to work forward; that is, it begins with the individual and lacks any preconceived notions about what that individual's family ought to look like. Starting with the individual at the center, we are able to work outward, tracing the web of that individual's tax family (i.e., all of the economically interdependent relationships in her life). Building on the firmer foundation that the individual return provides, this Article outlines a proposal for an individual tax filing system that, where appropriate, recognizes all economically interdependent relationships for tax purposes-and not only those patterned after the traditional family headed by a married differentsex couple.

In contrast to the recent proposals that accept the traditional family norm and build on it, this proposal is more in keeping with, and better takes account of, "the growing complexity of American households." ${ }^{.4}$ At the time of the 2000 census, $51.7 \%$ of all U.S. households were headed by married different-sex couples. ${ }^{5}$ This represented a significant decrease from the 1990 census, when about $55.2 \%$ of all U.S. households were headed by married different-sex couples. ${ }^{6}$ Notably, this decrease occurred despite a $15 \%$ increase in the total number of U.S. households (from 91.9 million to 105.5 million) between 1990 and 2000, including an increase in the absolute number of households headed by married different-sex couples (from 50.7 million to 54.5 million). ${ }^{7}$ The remaining $48.3 \%$ of U.S. households counted in the 2000 censùs were comprised of single-person households $(25.8 \%$ of all U.S. households), family households headed by a woman with no husband present $(12.2 \%$ of all U.S. households), family households headed by a man with no wife present $(4.2 \%$ of all U.S. households), and multiperson households in which the individuals were not related by marriage, birth, or adoption $(6.1 \%$ of all U.S. households). ${ }^{8} \mathrm{All}$ of these nontraditional households increased as a percentage of the total number of U.S. households between 1990 and $2000{ }^{9}$ In addition, the number of unmarried-partner households (which would fall into the larger category of multiperson households in which the individuals are not related by marriage, birth, or adoption) increased from $3.5 \%$ of all U.S. households in 1990 to $5.2 \%$ of

${ }^{3}$ See I.R.C. $\S 6013(a)$ (2006) (providing that only "a husband and wife" may file a joint return).

${ }^{4}$ Tavia Simmons \& Grace O'Neill, U.S. Census Bureau, Census 2000 Brief: HOUSEHOLDS AND FAMILIES: 2000, at 1 (2001), available at http://www.census.gov/prod/ 2001 pubs/c2kbr01-8.pdf.
${ }^{5} \mathrm{Id}$. at 2 tbl. 1 .
${ }^{6} \mathrm{Id}$. at 3 fig. 2 .
${ }^{7} \mathrm{Id}$. at 1 .
${ }^{8} I d$. at 2 tbl.1.
${ }^{9}$ Id. at 3 fig. 2 . 
all U.S. households in $2000 .^{10}$ This complexity in the composition of U.S. households has been growing for some time; indeed, for decades, the percentage of married-partner households has been declining and the percentage of nontraditional households has been increasing in the United States. ${ }^{11}$

These diverse households - as well as the many relationships that are overlooked by the census because they span the households that it is designed to count-are connected by an equally diverse array of ties, including familial, social, emotional, and economic ties. The focus of this proposal is, however, on only one set of these ties; namely, the economic ties that bind individuals together. These ties might take the form of the financial support that same-sex or different-sex spouses or partners provide each other, that parents and children or stepparents and stepchildren provide each other, that siblings or other relatives provide each other, or that friends or neighbors provide each other. This financial support might take the form of a transfer of cash or property (or of the use of cash or property) that is entirely gratuitous, in exchange for less than full consideration, or motivated by gratitude for services, support, or kindness that the other person provided with no expectation of payment or profit whatsoever. ${ }^{12}$

I have chosen to narrow my focus in this way because the income tax is most naturally suited to supporting and accommodating-or at the very least, to refraining from interfering with - the economic aspects of the relationships that individuals enter into. Conversely, the income tax is, on the whole, poorly suited to providing support for the noneconomic aspects of personal relationships, which can usually be better accommodated through changes or adjustments to other areas of the law or through nonlegal means. To take a simple example, the income tax is well suited to providing incentives for the equal sharing of financial resources within families, but it is not well suited to fostering an atmosphere of mutual respect within families or to deterring domestic violence. It is thus appropriate to

${ }^{10} \mathrm{Id}$. at 7.

${ }^{11}$ Jason Fields, U.S. Census Bureau, Population Characteristics: America's FAMILIES AND LIVING ARRANGEMENTS: 2003, at 4 fig.2 (2004), available at http://www.census.gov/prod/2004pubs/p20-553.pdf.

${ }^{12}$ I would like to draw attention to my deliberate use of the word "interdependence" (and variants of it) throughout this Article. I eschew use of the term "dependent" here because, despite being a common term used throughout the Internal Revenue Code, see, e.g., I.R.C. $\S \S 21,24,105,132,152$ (2006), it connotes an almost parasitic type of relationship. Instead, I contemplate here relationships of give and take. Thus, for example, even though a parent might be providing financial support to a child today, that relationship usually reverses sooner or later with the child providing support to the parent as she ages. In addition, a spousal relationship might involve one spouse contributing financial resources to the relationship through paid labor while the other performs labor in the home. Furthermore, one friend might help out another financially because that friend has provided care and emotional support in the past. 
focus our attention on the economic dimension of relationships, because that dimension is most relevant to, and most readily affected by, the income tax. ${ }^{13}$

By abandoning the joint return and replacing it with a system of mandatory individual filing that recognizes all economically interdependent relationships, this proposal would "decentralize" family in two very important ways. First, by embracing individual filing, we would achieve relationship (and not just marriage) neutrality in our income tax. This would have the salutary effect of making the traditional, nuclear family less central to the application of so many of the provisions in our federal income tax laws. Second, by recognizing all economically interdependent relationships and not just those relationships patterned after the traditional family, we would decentralize the definition of family. Rather than determining which relationships tend to be marked by economic interdependence based on preconceived notions of what a family should look like, economically interdependent relationships would be determined by reference to actual taxpayer behavior. In other words, each taxpayer would get to choose her tax familywhich might include a spouse, children, siblings, parents, cousins, friends, neighbors, or some combination of these or other people - instead of having a onesize-fits-all tax family imposed on her by the federal government. ${ }^{14}$ Put differently,

${ }^{13}$ I have detailed elsewhere the perils of maintaining too blinkered a focus on the economic dimension of individuals when assessing the fairness of a tax system. See generally Anthony C. Infanti, Tax 55 BUFF. L. REV. 1191 (2008). In this Article, I have avoided placing undue focus on the economic dimension of individuals through my starting point for analysis. Most discussions of the tax treatment of same-sex couples (to take one example of a nontraditional family) start from the horizontal equity premise that all economic units should be taxed equally (a premise that is usually implicitly qualified by the notion that an economic unit is one that looks like a traditional family). See id. at 121215. I eschew that starting point here in favor of beginning outside the tax system and its academic notions of appropriate economic units. I instead start from the premise that, though we are each individuals, we form webs of connections with other individuals, and as discussed in the text above, the fabric of these webs of connections is only growing increasingly diverse and complex. With this (nontax) reality as a starting point, the question then becomes how the tax system can best accommodate or support-or, at the very least, refrain from interfering with-the formation of this variety of relationships. Because, in its everyday application, the tax system largely concerns itself with the economic aspects of transactions between individuals, attempting to render the tax system neutral with regard to the economic dimension of interpersonal relationships seems the most appropriate means of ensuring that the tax system does not impede the formation of personal relationships. By starting outside of the tax system and refusing to apply traditional notions of tax fairness (which focus inordinately on the economic dimension of individuals), we are thus able to work toward a tax system that is fairer along multiple noneconomic lines (e.g., gender and sexual orientation).

${ }^{14}$ In theory, it might be possible to separate the two core parts of this proposal; that is, it is certainly possible to design an individual filing system without accommodating all economically interdependent relationships or to have a joint filing system that attempts to accommodate economically interdependent relationships. But, separating the proposal into 
the government would cease to be in the business of creating tax incentives for the formation of only a certain type of family and would instead begin to respect the autonomy and liberty of each individual to enter into whatever relationships are important to her.

This Article will proceed in four parts. Part II discusses the abolition of the joint federal income tax return in favor of mandatory individual filing. Given the extant, rather abundant literature on this question, Part II merely summarizes the main arguments that commentators have made against joint filing and in favor of individual filing, and then explains how individual filing is better equipped to recognize the diversity of economically interdependent relationships between individuals in our society. Part III turns to a brief description of the Canadian individual filing system. Canada has a well-established, nearly century-old individual filing system. Looking to the Canadian system for guidance in developing an individual filing system for the United States is particularly appropriate given both (1) Canada's long experience with individual filing and (2) a recent Law Commission of Canada report advocating changes to the Canadian tax system in order to recognize the diversity of relationships that Canadians enter into. Part IV outlines a proposed individual filing system for the United States that moves "beyond conjugality" (to borrow a phrase from the Law Commission of Canada) and seeks to recognize the many-and varied-economically interdependent relationships that we establish throughout our lives. Part IV also further elaborates on the reasons for focusing this proposal on the economic dimension of interpersonal relationships. Part $\mathrm{V}$ provides brief concluding remarks.

two components produces a less than desirable result. On the one hand, an individual filing system that failed to accommodate economically interdependent relationships would be based on the unrealistic assumption that we are all atomistic individuals without any relevant connections to each other and would, in all likelihood, serve only to impede the development of the economic dimension of personal relationships. More probable, however, is that such a system would be designed to accommodate only certain economically interdependent relationships; indeed, as described in Part II, infra, to the extent that commentators have developed proposals for individual filing systems, those proposals have revolved around the effect of individual filing on (and only on) the traditional family. On the other hand, even if a joint filing system did attempt to accommodate economically interdependent relationships, the existence of joint filing would still privilege certain relationships over others (at the very least, those composed of two individuals and, again more probably, those composed of two individuals in a conjugal relationship). It is only through the synergy achieved by uniting the two parts-individual filing and accommodating economically interdependent relationships-that the proposal can achieve the desired result of decentralizing family for tax purposes. 


\section{MANDATORY INDIVIDUAL TAX RETURN FILING}

\section{A. Background}

Though it is often described as adopting the individual as the basic taxable unit, ${ }^{15}$ the U.S. federal income tax has been more colorfully described as a "patchwork . . . of compromises" that evidence a "tension between rugged individualism and family solidarity." 16 This patchwork developed over an extended period. In its early years, the U.S. federal income tax "was dominated by an individualistic approach."17 Since then, Congress has departed in important ways from the individual baseline and moved toward viewing the traditional, nuclear family as the taxable unit. For example, in 1948, Congress introduced the incomesplitting joint return for married (different-sex) couples. ${ }^{18}$ Three years later, in 1951 , Congress created a separate rate schedule for heads of household in response to complaints that they had family responsibilities similar to those of married (different-sex) couples. ${ }^{19}$ This rate schedule provided heads of household with "a tax liability for a given amount that was midway between the liability for a single person and that of a married couple filing a joint return. ${ }^{; 20}$ Responding another three years later to complaints from those recently widowed and suddenly deprived of the benefit of the income-splitting joint return, Congress extended the benefit of income splitting to certain surviving spouses in $1954 .^{21}$ As a result of these incremental changes, there are now five separate categories for filing status on the Form 1040 (i.e., single, married filing jointly, married filing separately, head of

is 1 Boris I. BitTKer \& LAWRENCE LOKKen, Federal TAXATION OF INCOME, ESTATES, AND GIFTS $\uparrow 2.3$ (3d ed. 1999) ("From its inception, . . . the federal income tax has been based on the ... view that every individual should be permitted to file a personal income tax return embracing his or her own income but not the income of the taxpayer's spouse, children, or other relatives.").

${ }^{16}$ Boris I. Bittker, Federal Income Taxation and the Family, 27 STAN. L. REV. 1389, 1391 (1975).

${ }^{17}$ Id. at 1400; see also Carolyn C. Jones, Split Income and Separate Spheres: Tax Law'and Gender Roles in the 1940s, 6 LAW \& HIST. REV. 259, 259 (1988) ("Before the income-splitting joint tax return for husbands and wives became a part of the Internal Revenue Code in 1948, the federal income tax was assessed essentially on an individual basis.").

${ }_{18}$ Revenue Act of 1948, Pub. L. No. 80-471, § 303, 62 Stat. 110, 115.

${ }^{19}$ Revenue Act of 1951, Pub. L. No. 82-183, $\S 301,65$ Stat. 452, 480; Bittker, supra note 16 , at 1417 .

${ }^{20}$ Bittker, supra note 16 , at 1417.

${ }^{21}$ Internal Revenue Code of 1954, Pub. L. No. 83-591, § 2, 68A Stat. 3, 8; Bittker, supra note 16 , at $1417-18$. 
household, and qualifying widow(er)), all of which speak to the individual's relationship to "traditional" marriage. ${ }^{22}$

Yet, "the joint filing provisions are just one example of a scheme of taxation where considerations of marital status are pervasive."23 For instance, in 1984, Congress fully embraced the idea of the married different-sex couple as a single economic unit for tax purposes when it took the last step toward making transfers of property between a husband and wife completely income, gift, and estate tax free. ${ }^{24}$ And, in 1986, Congress enacted the "kiddie tax" that makes the family a quasi-taxable unit (at least with respect to the unearned income of minor children). ${ }^{25}$ These are just a few of the "[m]any features of the Federal Income Tax Code [that] reflect the assumption that our society is composed of heterosexual married couples, with men occupying the 'public' sphere and women occupying the "private' domestic sphere."26

This privileging of the traditional, nuclear family in tax policy debates has not been without controversy. In particular, academic commentators have sharply criticized the joint federal income tax return and many have called for its repeal. The joint federal income tax return as we now know it did not make its way onto the U.S. tax scene until some thirty-five years after the ratification of the Sixteenth

${ }^{22}$ I.R.S. FORM 1040: U.S. INDIVIDUAL INCOME TAX RETURN 1 (2009). Naturally, "married" (whether filing jointly or separately) refers to an individual who is currently a party to a state-sanctioned different-sex marriage, see 1 U.S.C. $\$ 7$ (2006) (recognizing only different-sex marriages for purposes of federal law); "widow(er)" refers to someone whose different-sex spouse has passed away; "single" refers not to the individual as such, but to an individual who is not currently married or widowed; and, as mentioned in the text above, "head of household" refers to someone who has obligations similar to those of a married (different-sex) couple. See I.R.S. INSTRUCTIONS FOR FORM 1040, at 14-16 (2009).

${ }^{23}$ Nancy J. Knauer, Heteronormativity and Federal Tax Policy, 101 W. VA. L. REV. $129,132(1998)$.

${ }^{24}$ H.R. REP. No. 98-432, at 1491 (1984); Patricia A. Cain, Death Taxes: A Critique from the Margin, 48 CLEV. ST. L. REV. 677, 680 (2000).

${ }^{25}$ Tax Reform Act of 1986, Pub. L. No. 99-514, § 1411, 100 Stat. 2085, 2714.

${ }^{26}$ Nancy C. Staudt, Taxing Housework, 84 GEO. L.J. 1571, 1571 (1996).

In the United States, to take an important example, tax systems, mainly created in the twentieth century-and hence generally free of the openly sexist language found in England and many Commonwealth societies-are not facially gendered. Yet major features of the American tax system were put in place in the $1930 \mathrm{~s}, 1940 \mathrm{~s}$, and $1950 \mathrm{~s}$, periods when the one-earner family with a stay-athome wife was both the descriptive fact and the normative ideal for most Americans. These structural elements persist, unmitigated and indeed often increased in their magnitudes, well into the 21 st Century.

Edward McCaffery, Where's the Sex in Fiscal Sociology?: Taxation and Gender in Comparative Perspective, in THE NEW Fiscal Sociology: TAXation IN COMPARATIVE AND HistoriCAL PERSPECTIVE 216, 217 (Isaac William Martin et al. eds., 2009). 
Amendment. After several failed attempts, ${ }^{27}$ Congress enacted the income-splitting joint return in $1948 .^{28}$ As mentioned above, prior to that time, the income tax "was dominated by an individualistic approach. ${ }^{, 29}$ Congress did not, however, make the decision to shift the focus so radically away from the individual on the basis of sound tax policy considerations, but instead did so as a politically expedient means of ending the movement among the states toward the adoption of communityproperty regimes that would allow their residents to save taxes by splitting their income. ${ }^{30}$ In moving toward community-property regimes, the states were acting in response to two earlier U.S. Supreme Court decisions. One of these decisions

${ }^{27}$ Bittker, supra note 16 , at $1408-11$.

${ }^{28}$ Revenue Act of 1948, Pub. L. No. 80-471, $\S 301,303$, 62 Stat. 110, 114, 115.

${ }^{29}$ Bittker, supra note 16, at 1400; see also Jones, supra note 17, at 259 ("Before the income-splitting joint tax return for husbands and wives became a part of the Internal Revenue Code in 1948, the federal income tax was assessed essentially on an individual basis.").

${ }^{30}$ S. REP. NO. 80-1013, at 26 (1948) ("Adoption of these income-splitting provisions will produce substantial geographical equalization in the impact of the tax on individual incomes. The impetuous enactment of community-property legislation by States that have long used the common law will be forestalled."); Bittker, supra note 16, at 1412-13 (suggesting that adoption of the income-splitting joint return had the same result as if Congress had stood "idly by while the whole country adopted the community property system, but enactment of the income-splitting joint return meant that the political credit for reducing taxes was concentrated on Congress rather than dispersed among the state legislatures"); Jones, supra note 17, at 295 (referring to Bittker's assertion quoted in the immediately preceding citation: "The real point of this state-versus-federal conflict was in the quality of relief provided. State legislatures could offer tax reduction only by altering married people's legal rights to income and property; Congress could and did offer tax reduction without any change in the legal rights between spouses."); id. at 296 ("The . . . income-splitting joint return was . . . more expensive than either the Gearhart bill [that would have recognized husband-wife income-splitting agreements] or allowing the states to adopt community-property legislation. While it possessed the virtue of ease of administration, it also was viewed as a way of conserving traditional gender roles and power relationships."); Lily Kahng, Innocent Spouses: A Critique of the New Tax Laws Governing Joint and Several Liability, 49 VILL. L. REV. 261, 272 (2004) ("The political motivation for the 1948 tax law change was to procure for husbands in common law states the lower tax burden enjoyed by their counterparts in community property states, thus rendering meaningless for tax purposes the stronger property rights of women in community property states and quelling the movement towards adoption of community property laws. The camouflage for the political motivation was the unfounded assertion that a married couple is a single unit and that equal-income marital units should bear the same tax burden no matter what their state of residence." (footnote omitted)); Lawrence Zelenak, Marriage and the Income Tax, 67 S. CAL. L. REV. 339, 347 (1994) ("Rather than being based on bedrock beliefs about the nature of marital sharing, the 1948 legislation was essentially a historical accident-a response to the geographic discrimination and legal confusion resulting from the combination of Lucas v. Earl and Poe v. Seaborn."). 
allowed full income splitting by married couples in community-property states, ${ }^{31}$ and the other disallowed the splitting of earned income by married couples in common-law states. ${ }^{32}$ Many of the current tax policy justifications for the incomesplitting joint return are thus little more than "after-the-fact rationalization[s]" for an essentially political compromise. ${ }^{33}$

\section{B. Critiques of Joint Filing}

In recent decades, U.S. commentators of all stripes have called for the abolition of the joint federal income tax return. These commentators have offered a multiplicity of reasons to support this suggested reform of the U.S. federal income tax filing system. The remainder of this section briefly summarizes some of the most salient and trenchant arguments against joint filing and in favor of individual filing.

The principal after-the-fact justification for permitting a "husband and wife"34 to file a joint return that splits their income for federal income tax purposes is that it reflects the fact that married couples act as a single economic unit by pooling their financial resources. ${ }^{35}$ Commentators have countered this justification by pointing out that the joint return is actually poorly targeted at those who act together as a single economic unit. In particular, Marjorie Kornhauser has used empirical data to demonstrate that the class of taxpayers permitted to file a joint

\footnotetext{
${ }^{31}$ Poe v. Seaborn, 282 U.S. 101, 118 (1930).

${ }^{32}$ Lucas v. Earl, 281 U.S. 111, 113-15 (1930); see also Poe, 282 U.S. at 117.

${ }^{33}$ Zelenak, supra note 30 , at 343.
}

In more recent scholarship, defenders of the joint return have argued that the income-splitting device provided by the joint return is more equitable than proposed alternatives because it treats a married couple as two individuals who equally benefit from their combined incomes. This defense, however, was articulated in a more sophisticated form post hoc, after the adoption of the joint return.

Jones, supra note 17, at 261 (footnotes omitted); see also Kahng, supra note 30, at 272 (describing the political motivation for enacting the joint return and referring to the "fiction" of marital unity). But see S. REP. NO. 80-1013, at 26 (1948) (citing the lessening of administrative burdens stemming from self-help income splitting by married couples in common-law states as a benefit of adopting the income-splitting joint return).

${ }^{34}$ I.R.C. $\$ 6013$ (a) (2006). In effect, "[j]oint returns subject all married couples with the same amount of taxable income to the same tax liability, regardless of how their income and deductions are divided between them." 4A BORIS I. BITTKER \& LAWRÉNCE LOKKEN, FEDERAL TAXATION OF INCOME, EstateS, AND GIFTS ๆ 111.3.2.1 (3d ed. 2000).

${ }^{35}$ See, e.g., Zelenak, supra note 30, at 344 ("The standard justification for joint returns is that the typical married couple pools its income."). 
federal income tax return is both over- and underinclusive. ${ }^{36}$ In reviewing the empirical data, Kornhauser has painted a complex picture in which some married couples pool their finances, others do not, and many send signals that contradict the outward appearance of their financial arrangement (e.g., by treating jointly held assets as separate property or separately held assets as joint property) ${ }^{37}$ As a result, the class of potential joint return filers is overinclusive because it includes many married different-sex couples who do not pool their financial resources or act as a single economic unit. ${ }^{38}$ Yet, at the same time, the class of potential joint return filers is underinclusive because it excludes many nontraditional families who actually do pool financial resources and act as a single economic unit. ${ }^{39}$

In the same vein, it has been argued that individual return filing is more

consistent with our tax system's basic principle that the person who controls the income should be taxed on it even if another benefits. The control principle is particularly apt for earned income since only the earner can produce that income. As the empirical studies show, the

${ }^{36}$ See generally Marjorie E. Kornhauser, Love, Money, and the IRS: Family, IncomeSharing, and the Joint Income Tax Return, 45 HASTINGS L.J. 63 (1997). Others have made similar points:

Although couples undoubtedly share income and operate as an economic unit to some extent, all couples at all income levels do not universally adopt this pattern for their entire income. Moreover, if this theory is a correct basis for assessing tax burdens, it incorrectly includes only sharing in households of married persons and ignores sharing by single adults who similarly divide their income with others.

Pamela B. Gann, Abandoning Marital Status as a Factor in Allocating Income Tax Burdens, 59 TEX. L. REV. 1, 31 (1980); see also Jeannette Anderson Winn \& Marshall Winn, Till Death Do We Split: Married Couples and Single Persons Under the Individual Income Tax, 34 S.C. L. REV. 829, 851 (1983) ("Although income splitting is best explained under the benefit theory, and by implication, the concept of income pooling, it is a tenuous justification."); Laura Ann Davis, Note, A Feminist Justification for the Adoption of an Individual Filing System, 62 S. CAL. L. REV. 197, 216-17 (1988) ("The use of marital status as a proxy for pooling is problematic in that marital status both overstates and understates the true incidence of pooling. The simple fact is that not all individuals who pool income are married and not all married individuals pool.").

For a different interpretation of the data that Kornhauser examined, see Zelenak, supra note 30 , at $348-54$.

${ }^{37}$ Kornhauser, supra note 36 , at 80-91.

${ }^{38} \mathrm{Id}$. at $105-06$.

${ }^{39}$ Id. at $106-07$. 
earner usually controls the income even if the couple states that they pool. $^{40}$

This argument is buttressed by others who have critiqued the joint and several liability that accompanies the filing of a joint federal income tax return. Lily Kahng has explained how joint and several liability can "produce unjust or irrational results." $"$ And Amy Christian has asserted that, when joint and several liability is considered together with the income-splitting and income-aggregation aspects of the joint return, "the joint return produces a powerful structural bias against wives. ${ }^{, 42}$

Another significant critique of the joint return is aimed not at after-the-fact justifications for its enactment but at the (dis)incentive effects that it creates in operation. A number of commentators have argued that joint filing contributes to the creation of a distinct tax disincentive for secondary earners-who are predominantly women-from entering the paid workforce. ${ }^{43}$ This disincentive results because the aggregation of the couple's income causes the secondary earner's wages effectively to be taxed beginning at the primary earner's marginal tax rate, depriving her of the benefit of the zero bracket amount and the lower initial brackets in the tax rate schedule (which have already been applied to, and exhausted by, the primary earner's income). Amy Christian has provocatively asserted that, by operating in this way, the joint return actually "redistributes resources from the lower-earning to the higher-earning spouse, that is, typically from the wife to her husband." ${ }^{, 44}$ Naturally, the obverse of this disincentive is a distinct tax incentive for secondary earners (again, predominantly women) to devote themselves to unpaid productive activity in the home:

[I]ncome splitting is most beneficial to couples in which one spouse earns significantly more than the other. The closer the incomes of the

${ }^{40} \mathrm{Id}$. at 109; see also Zelenak, supra note 30 , at $354-58$ (asserting that joint filing is more consistent with a focus on consumption of income and that individual filing is more consistent with a focus on the control of income).

${ }^{41}$ Kahng, supra note 30, at 290.

${ }^{42}$ Amy C. Christian, Joint and Several Liability and the Joint Return: Its Implications for Women, 66 U. CIN. L. REV. 535, 537 (1998); see id. at 604-15 (explaining this point).

${ }^{43}$ Grace Blumberg, Sexism in the Code: A Comparative Study of Income Taxation of Working Wives and Mothers, 21 Buff. L. REV. 49, 88-95 (1971); Amy C. Christian, The Joint Return Rate Structure: Identifying and Addressing the Gendered Nature of the Tax Law, 13 J.L. \& PoL. 241, 287-303 (1997); Gann, supra note 36, at 39-46; Kornhauser, supra note 36, at 109-10; Edward J. McCaffery, Taxation and the Family: A Fresh Look at Behavioral Gender Biases in the Code, 40 UCLA L. REV. 983, 989-96, 1014-29 (1993); Winn \& Winn, supra note 36, at 869-70; Zelenak, supra note 30, at 365-66; Davis, supra note 36 , at 210-14.

${ }^{44}$ Christian, supra note 43 , at 364 ; see also id. at $305-48$ (furnishing the explanation for this assertion). 
two spouses, the less benefit income splitting confers. Therefore, income splitting provides a tax benefit primarily to couples who fit traditional roles in which the husband earns most or all of the income and in which the wife does not work. . . The benefit of income splitting is minimal for couples in which the spouses earn similar amounts, that is, for couples whose working patterns defy traditional, stereotypical roles in which the husband is gainfully employed and the wife is not. In fact, the benefit is nonexistent if the spouses earn equal incomes. By benefiting disparate-income couples, the income-splitting feature of the joint return rewards working patterns that conform to sexist stereotypes while failing to reward taxpayers who challenge the stereotype. One may question the propriety of a tax system containing a benefit whose availability and amount is tied to how closely the couple fits a sexist stereotype. ${ }^{45}$

Dorothy Brown has, however, drawn attention to the essentialism of these arguments by pointing out that women's occupation of the secondary earner slot varies significantly based on race and class; in other words, when the data is broken down by race and class--rather than simply being aggregated for all women-there are categories in which the woman is a different-sex couple's primary or equal earner. ${ }^{46}$

The joint return has been assailed-and the individual return has been. advocated - on a number of other grounds. For example, commentators have argued that we should abandon the joint return and adopt mandatory separate filing to achieve a marriage-neutral income tax.$^{47}$ Lily Kahng has taken this argument a step further by highlighting the negative impact of the joint return on single people, and she has advocated repeal of the joint return as a means of facilitating single people's ability to move forward in forging a positive social identity. ${ }^{48}$

Toni Robinson and Mary Moers Wenig have argued against the joint return on administrability grounds. They have assailed the use of marital status as a determinant of tax liability on the ground that it has given rise to a multiplicity of rules regarding who is (or is not) married for tax purposes, adding unnecessary levels of complexity to our income tax system:

A review of the details of the marital status definitions confirms that marital status is an unsatisfactory criterion. Its use requires arbitrary definitional choices. Yet it fails as a measure of ability to pay and

${ }^{45} I d$. at $279-80$ (footnotes omitted).

${ }^{46}$ Dorothy A. Brown, Race, Class, and Gender Essentialism in Tax Literature: The Joint Return, 54 W ASH. \& LEE L. REV. 1469, 1488-1507 (1997).

${ }^{47}$ Gann, supra note 36, at 32-39; James E. Maule, Tax and Marriage: Unhitching the Horse and the Carriage, 67 TAX NOTES 539, 548-49 (1995).

${ }^{48}$ Lily Kahng, One Is the Loneliest Number: The Single Taxpayer in a Joint Return World, 61 HASTINGS L.J. 651, 683-84 (2010). 
produces aberrational results. If a taxpayer can obtain advice as to his marital status for tax filing purposes only from "someone highly informed with respect to tax law" the definition is an unacceptable determinant. If he still needs expert help when he pursues his petition to the Tax Court (when the advice comes too late), the tax law of marital status demands simplification. ${ }^{49}$

Returning to the impact of the joint return on women, commentators have argued that mandatory separate filing would create a salutary incentive for husbands to transfer property to their wives to achieve a measure of income splitting, which under the current joint filing system can be achieved without the actual sharing of property. ${ }^{50}$ In addition, it has been argued that an individual return system would allow for better targeting of tax incentives aimed at children, because, "[a]rguably, there is a better chance that the money would be spent for the children if the woman gets the credit. Studies show that women are more likely than men to allocate more of their earnings to children."

\section{International Trend Toward Individual Filing}

When viewed from a wider, international perspective, advocates of individual filing can also find support for their proffered reform in the practice of other countries. As the Congressional Budget Office has explained:

The United States is among a minority of developed nations that tax married couples. More than two-thirds of the countries that are members of the Organization for Economic Cooperation and Development (OECD) tax married couples as individuals. Only three other developed countries tax couples jointly as does the United States, and four others tax all family members as a single entity .... Furthermore, the trend has been moving away from joint taxation.... 52

49 Toni Robinson \& Mary Moers Wenig, Marry in Haste, Repent at Tax Time: Marital Status as a Tax Determinant, 8 VA. TAX REV. 773, 791-92 (1989) (footnotes omitted) (quoting Forrest v. Comm'r, 37 T.C.M. (CCH) 1033, 1038 (1978)).

${ }^{50}$ E.g., Gann, supra note 36, at 46-51.

${ }^{51}$ Kornhauser, supra note 36, at 110.

52 CONG. Budget OfFice, U.S. CONG., For BetTer OR fOR WORSE: MARRIAGE AND THE FEDERAL INCOME TAX 8 (1997); see also id. app. A; ORG. FOR ECON. CO-OPERATION \& Dev., OECD TAX Policy Studies No. 13, Fundamental Reform of Personal INCOME TAX 54 (2006) ("Many OECD countries have moved away from family-based taxation towards individually based systems . . . . Seventeen of the OECD countries used pure individual taxation and four countries . . . used pure joint taxation of earnings in 2005."); McCaffery, supra note 26, at 6-8 (describing the international trend toward individual filing, but noting that the Czech Republic bucked that trend when it adopted joint filing in 2005). 


\section{Recognizing the Diversity of Relationships}

Given the incisive critiques of joint filing described above and the clear international trend toward individual filing, it would seem that rectifying discrimination against nontraditional families by slightly widening the circle of privileged relationships that are permitted to file joint returns is more of a step backward than a step forward. As Nancy Knauer has keenly observed with regard to proposals to extend joint filing to same-sex couples:

To the extent same-sex couples want the tax code to recognize their relationships, they are at odds with the emerging consensus that the individual and not the married couple should be the appropriate unit of taxation. Thus, lesbian and gay scholars seem to be asking for inclusion in the very regime that other progressive scholars are trying to dismantle in the name of greater female autonomy. ${ }^{53}$

A more inclusive approach would not simply seek out additional family forms in the mold of the traditional family, but would attempt to recognize and accommodate the multiplicity and complexity of family relationships and the webs of connections between individuals that actually exist in society.

Individual filing lends itself much more easily to this endeavor than does joint filing. Joint filing begins with a certain type of relationship in mind, namely, that of the conjugal couple. This preestablished framework inevitably skews the search toward other similar relationships that then seem appropriate candidates for inclusion in an expanded joint filing regime. In contrast, individual filing begins with no preconceived notions about the relationships that an individual might enter into. An individual filing system is thus more malleable because it can be shaped to fit the actual social relationships that the individual enters into-as opposed to joint filing, which attempts to fit complex social relationships into preconceived molds codified in the tax laws.

In keeping with the family theme of this Article, it may help to think of these two filing systems as being akin to two different shape-sorters-those educational children's toys that typically consist of a wooden board with cutouts in a variety of shapes and an equal number of wooden blocks of corresponding shape that the child attempts to place in the appropriate cutout. ${ }^{54}$ Joint filing is like a shape-sorter with only a single cutout (e.g., a circle) but a variety of wooden blocks (e.g., a circle, a square, a rectangle, a triangle, an oval, etc.). A child playing with this board would simply learn to sort the circle out of all of the other blocks. The circle

${ }^{53}$ Knauer, supra note 23, at 157.

${ }^{54}$ On the benefits of shape sorter toys, see Alison Bell, The Benefits of Shape-Sorter Toys, PARENTING, http://www.parenting.com/article/Baby/Gear/The-Benefits-of-ShapeSorter-Toys (last visited July 18, 2010). 
would fit within the cutout and all of the other blocks would simply be put to the side in a pile of non-circles. Instead of learning about the diversity of shapes that exist in the world, the child would learn that only one shape matters: circles. Individual filing is more like the typical shape-sorter; that is, a board with a wide variety of cutouts corresponding to the same wide variety of wooden blocks. This version of the toy privileges no single shape; rather, each shape has its place and can be accommodated on the board.

The skewing effect of adopting joint filing is evidenced in the course of the tax policy debate since the adoption of the income-splitting joint return. Ever since that time, the tax policy debate regarding the appropriate taxable unit has revolved around the traditional, nuclear family and its core-the different-sex couple united in marriage. As mentioned above, the debates in the 1950s about the appropriate taxation of heads of household and then widows and widowers

responded to the complaint of unmarried taxpayers with dependents that their family responsibilities were comparable to those of married couples. But the provisions [for heads of household and widow(er)s] did not question-indeed, they implicitly ratified - the tax differential established in 1948 between a married couple and a single person with the same income. ${ }^{55}$

Since the 1969 change in the rate schedule to reduce the singles penalty, the tax policy debate has been focused on the competing ideals of "marriage" neutrality and "couples" neutrality (read: different-sex married couples neutrality) and on the associated questions of whether penalties should be imposed on those who are married or those who are unmarried and of whether the tax laws should encourage or discourage marriage. ${ }^{56} \mathrm{~A}$ natural concomitant of this unbending focus on the traditional family is that all other types of relationships are ignored in this debate.

If we wish to recognize and accommodate the multiplicity and complexity of family relationships and the webs of connections between individuals that actually exist in society, it would seem that the first natural step would be to abandon our extant joint filing regime. Indeed, Kathy, Lahey has observed that this is precisely what has occurred when societies move away from a rigid adherence to the traditional family form:

[J]oint models of the tax unit tend to be replaced with individual models as relationships recognized in law become more diverse, as sex roles become more egalitarian, as social values become less "traditional" and inclusive, as women gain direct legal interests in incomes and assets, and as the state assumes more responsibility for the welfare of children. ${ }^{57}$

${ }^{55}$ Bittker, supra note 16 , at 1418 .

${ }^{56}$ See id. at 1430.

57 Kathleen A. Lahey, The Benefit/Penalty Unit In Income TaX Policy: DIVERSITY AND REFORM 25 (2000), available at http://dsp-psd.pwgsc.gc.ca/collection_ 
Accordingly, this Article adopts individual filing as the starting point for fashioning a tax system that decentralizes family.

The adoption of an individual tax filing system in the United States is not as politically unrealistic as other commentators believe. ${ }^{58}$ In fact, Sweden taxed the family as a unit for centuries following the initial inception of its income tax in 1710; however, it gradually moved to an individual tax filing system in response to demographic changes during the twentieth century. In 1960, Sweden moved to an ascriptive definition of marital status that included unmarried cohabitants that was designed to put an end to the practice of high-income couples either cohabiting outside of marriage or obtaining a "tax divorce" (i.e., a couple would divorce, live apart long enough to convince the tax authorities that the divorce was bona fide, and then secretly move back in together). ${ }^{59}$ Women's organizations in Sweden began to criticize joint filing in the early 1960 s on the ground that it created a disincentive for women to enter the labor force because, as described above, they would begin to be taxed at their husband's marginal tax rate ${ }^{60}$ Because these complaints coincided with a labor shortage in the country, the government swiftly enacted reforms, first providing an individual filing option for earnings in 1965 and then abolishing the joint taxation of earnings in $1970 .^{61}$ Sweden later moved to the separate taxation of unearned income as well. ${ }^{62}$ Given the continuing demographic changes in the United States described in the introduction to this Article, individual tax filing should only become increasingly politically palatable as time passes.

An individual filing system is, however, only a starting point for fashioning a tax system that decentralizes family. The next step in the analysis is to consider the ways in which an individual filing system should take into account the economically interdependent connections and relationships that many of us have. Unfortunately, most U.S. commentators end their analyses with a call to abolish the joint federal income tax return and devote little attention to the appropriate

2008/lcc-cdc/JL2-46-2000E.pdf.

${ }^{58}$ Motro, supra note 2, at 1513; see Lawrence Zelenak, Doing Something About Marriage Penalties: A Guide for the Perplexed, 54 TAX L. REV. 1, 2-3 \& n.11 (2000) (indicating his belief that mandatory individual feeling is not a political possibility in the near future, but that it is a possibility in the long run).

${ }^{59}$ Louise Dulude, Taxation of the Spouses: A Comparison of Canadian, American, British, French and Swedish Law, 23 OsGOODE HALL L.J. 67, 80 (1985); see LAHEY, supra note 57 , at 27 (indicating that Sweden gradually moved to individual filing from joint filing during the 1950s and 1960s).

${ }^{60}$ Dulude, supra note 59 , at 80.

${ }^{61}$ Id. at 81.

62 Hugh J. ault et al., Comparative income taxation: A Structural ANALYSIS 262-63 (2d ed. 2004). 
design for an individual filing system. ${ }^{63}$ In the few cases where commentators have explored the implementation of an individual filing system, they have focused their attention almost exclusively on whether-and, if so, how-that system should continue to accommodate financial transactions between married different-sex spouses. ${ }^{64}$ This Article departs from these contributions to the literature by widening the focus to consider how to design an individual filing system that accommodates transactions between all economically interdependent individualsand not only those in marriage or marriage-like relationships.

Before developing a proposal for accommodating transactions between economically interdependent individuals in the context of an individual filing system, the next section of this Article sketches the contours of individual taxation in Canada. It has been said that Canada "has the most extensive system of individual taxation." ${ }^{, 65}$ In Canada, "[t]he individual has always been the taxable unit, though there has been periodic discussion to establish spouses or the family as the taxable unit." ${ }^{, 66}$ Looking to Canada's long experience with an individual filing system will be helpful in fashioning a proposal for adoption in the United States. A recent report issued by the Law Commission of Canada makes that country an even more appropriate choice in looking elsewhere for guidance on developing an individual filing system. In that report, the Law Commission advocated reconsidering the relevance of relationships to Canadian law-including Canadian tax law-to determine whether the law might not be revised to recognize the broad diversity of relationships entered into by Canadians rather than merely recognizing conjugal relationships. ${ }^{67}$

${ }^{63}$ See Brown, supra note 46, at 1485-86 ("The most popular solution the literature proposes is the abolition of the joint return .... Although acknowledging the difficulty in implementing ... a a $n$ individual return] system, most commentators have not attempted to work through the difficult theoretical issues."); Zelenak, supra note 30, at 381 ("If spouses are required to file separate returns there must be rules for determining how income (especially property income), deductions, and credits are allocated between the spouses. For the most part, advocates of separate returns have given scant consideration to these design issues.").

${ }^{64}$ E.g., Gann, supra note 36 , at 52-67; Winn \& Winn, supra note 36 , at $870-80$; Zelenak, supra note 30, at 381-401; Davis, supra note 36, at 235-48; see also STAFF OF JoINT COMM. ON TAXATION, THE INCOME TAX TREATMENT OF MARRIED COUPLES AND SINGLE PERSONS 38-46 (1980) (discussing technical issues relating to the implementation of separate filing for married couples).

${ }_{65}$ AULT ET AL., supra note 62, at 267.

${ }^{66}$ Id. at 261; see also LAW COMM'N OF CAN., BEYOND CONJUGALITY: RECOGNIZING AND SUPPORTING Close PERSONAL AdUlt RELATIONSHIPS 67 (2001) [hereinafter BEYOND CONJUGALITY], available at http://www.samesexmarriage.ca/docs/beyond_conjugality.pdf.

${ }^{67}$ See BEYOND CONJUGALITY, supra note 66, passim. 


\section{INDIVIDUAL TAXATION IN CANADA}

\section{A. Background}

The Canadian Income Tax Act (ITA) ${ }^{68}$ requires each individual to file a separate return reporting his or her income tax liability under a single progressive rate schedule. ${ }^{69}$ Canada has had an individual filing system since the introduction of its income tax in $1917 .^{70}$ In the context of a comparative survey of individual versus joint filing in five different countries, Louise Dulude attributed Canada's early adoption of individual filing (as well as the United States' initial embrace of individual filing) to the influence of the underlying property law treatment of ownership by women. ${ }^{71}$ Thus, in Canada (and the United States), women "had gained control of their property when the first permanent income tax provisions were introduced ... , [and] it was taken for granted that the taxpayer would be the individual." ${ }^{, 72}$ In contrast, in France, Great Britain, and Sweden, the husband had control of the family's property at the time that an income tax was introduced in those countries, and the tax laws initially followed suit by treating the couple or family as the taxable unit. ${ }^{73}$

Despite Canada's longstanding adherence to an individual system of taxation, there has been a recurring debate about whether the family is a more appropriate taxable unit. ${ }^{74}$ In fact, in 1966, the Royal Commission on Taxation (commonly called the Carter Commission, after its chair, Kenneth Carter) recommended that "Canada abandon separate taxation in favour of a taxpaying unit which would include the spouses and their dependent children." 75 The Canadian federal government rejected this proposal in 1969, in significant part due to the actual or perceived opposition of women to the change. ${ }^{76}$ Then, in the mid-1970s, the federal Interdepartmental Committee on the Taxation of Women evenly split on the question of the taxable unit, with half of its members favoring joint filing and half favoring retention of individual filing of returns. ${ }^{77}$ Since that time,

\footnotetext{
${ }^{68}$ Income Tax Act, R.S.C., c. 1 (5th Supp. 1985) (Can.) [hereinafter ITA].

${ }^{69} \mathrm{Id}$. $\S \S 117(2), 150(1)$.

${ }^{70}$ Dulude, supra note 59 , at $81-82$.

${ }^{71} I d$. at 87.

${ }^{72} \mathrm{Id}$.

${ }^{73}$ Id. Great Britain and Sweden have since moved to individual filing systems. AULT ET AL., supra note 62, at 262-63.

${ }^{74}$ Joyce M. Crago, The Unit of Taxation: Current Canadian Issues, 52 U. TORONTO

FAC. L. REV. 1, 2 (1993).

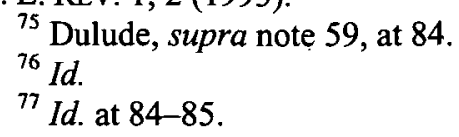


commentators have regularly debated whether the individual or the family is the appropriate taxable unit for purposes of the Canadian federal income tax. ${ }^{78}$

Even under Canada's system of individual filing, family responsibilities do creep into (and have increasingly crept into) the tax calculation. ${ }^{79}$ Thus, notwithstanding the inability to file a joint return, there is a section of the Canadian income tax return where the taxpayer must indicate his or her marital status (i.e., married, in a common-law partnership, widowed, divorced, separated, or single). ${ }^{80}$ Notably, Canada recognizes not only same-sex and different-sex couples who have married, but it also recognizes unmarried same-sex and different-sex common-law partners. For tax purposes, "common-law partner" is defined as "a person who cohabits . . . in a conjugal relationship with the taxpayer" and either (1) "has so cohabited with the taxpayer for a continuous period of at least one year" or (2) is the parent of a child who is also the taxpayer's child. ${ }^{81}$

To get a sense of the extent to which marital and/or familial status may affect the application of the Canadian federal income tax laws despite the nominally

${ }^{78}$ E.g., LAHEY, supra note 57, passim; Jasvinder S. Basran, Individual or Family: Beyond Ability to Pay, an Examination of the Appropriate Unit of Tax in Relation to the Broad Goals and Policies of the Canadian Tax System, 57 SASK. L. REV. 349 passim (1993); Neil Brooks, The Irrelevance of Conjugal Relationships in Assessing Tax Liability, in TAX UNITS AND THE TAX RATE SCALE 35 (John G. Head \& Richard Krever eds., 1996); Crago, supra note 74, passim; Kathleen Lahey, Heteronormativity, Equality, and the Family: Beyond the Freedom to Marry, 4 J.L. \& EQUALITY 117, 137-44 (2005); Kathleen A. Lahey, The Tax Unit in Income Tax Theory, in WOMEN, THE LAW, AND THE ECONOMY 277 passim (Diane E. Pask et al. eds., 1985) [hereinafter Lahey, Tax Unit]; Jack London, The Family as the Basic Tax Unit, 1 CAN. TAX'N 4 passim (1979); Jack R. London, The Impact of Changing Perceptions of Social Equity on Tax Policy: The Marital Tax Unit, 26 OSGOODE HALL L.J. 287 passim (1988) [hereinafter London, Marital Tax Unit]; Maureen Maloney, Women and the Income Tax Act: Marriage, Motherhood, and Divorce, 3 CAN. J. WOMEN \& L. 182 passim (1989); Samuel A. Rea, Jr., Taxes, Transfers, and the Family, 34 U. TORONTO L.J. 314 passim (1984); see BEYOND CONJUGALITY, supra note 66, at 66 (acknowledging the debate); $i d$. at 67-71 (making the case for retaining the individual as the taxable unit in Canada); see also Judith E. Grbich, The Tax Unit Debate Revisited: Notes on the Critical Resources of a Feminist Revenue Law Scholarship, 4 CAN. J. WOMEN \& L. 512 passim (1990) (providing a critique of the neoclassical economic underpinnings of this debate and urging the use of alternative methodologies).

${ }^{79}$ See LAHEY, supra note 57, at 29 ("[T]he Canadian income tax system . . . has used the individual as the tax unit from the outset. However, it has consistently focused special benefits on married couples only, and those benefits have increased in number and value over the last century." (emphasis omitted)); Crago, supra note 74, at 4 ("In the years since the Carter Commission, there has been a gradual change in the income tax system to recognize the family as the unit of taxation."); Dulude, supra note 59, at 109 ("The basic principle of individual taxation is that each person pays tax on his or her own income, with deductions or credits being used to recognize family responsibilities.").

${ }^{80}$ Can. Revenue Agency, Form T1 General 2008: InCOME TAX AND Benefit RETURN 1 (2008), available at http://www.nevcon.com/forms/2008-t l-general.pdf.

${ }^{81}$ ITA $\S 248(1)$. 
individual application of the tax, I downloaded a full copy of the federal Income Tax Act from the Canadian Department of Justice's Web site. ${ }^{82}$ I then did a few quick searches for selected words and phrases indicative of a concern with marital and/or familial status. This (admittedly unscientific) search yielded 604 hits for the word "spouse," 523 hits for the phrase "common-law" (as in common-law partner or common-law partnership), 27 hits for the word "married," 475 hits for the word "child" (or its plural, "children"), and 128 hits for the word "family." ${ }^{, 83}$ Quite understandably, then, one commentator has labeled the Canadian federal income tax as being based on "a modified-individual tax unit."

In the Canadian income tax system, marital or familial status can either increase or decrease tax benefits, depending upon "the amount of income of each of the partners, the nature of that income and the relative distribution of that income as between the partners." ${ }^{\text {" } 5}$ It may work to decrease tax benefits, for example, when calculating the goods and services tax/harmonized sales tax credit and the Canada child tax benefit, both of which are phased out based on the combined income of spouses or common-law partners. ${ }^{86}$ In addition, for purposes of the exclusion for gain on the disposition of a principal residence, each family is limited to designating a single principal residence at any given time.${ }^{87}$ Conversely,

${ }^{82}$ ITA, available at http://laws.justice.gc.ca/PDF/Statute/I/I-3.3.pdf.

${ }^{83}$ For a similar tabulation, see LAHEY, supra note 57, app. A. Lahey states that this tabulation indicates that "[a]t least a hundred federal income tax provisions look not only to spousal status but to other forms of relationship, including 'family' relationship." Id. at 5 n.10. Likewise, the Law Commission of Canada has explained:

The Income Tax Act contains a bewildering variety of provisions that refer to the personal relationships of the individual taxpayer. For example, there are over 200 provisions in the Act and the regulations to the Act that contain references to the phrase (or variations of it) "spouse and common-law partner." The Act contains over 500 references to the concept of "related person," which includes, basically, all persons related by blood or adoption to the taxpayer and their spouses and common-law partners. These provisions are so diverse that it is difficult to generalize about the reasons why relational status is used in many of them.

\section{BEYOND CONJUGALITY, supra note 66 , at 72 .}

${ }^{84}$ Crago, supra note 74, at 6; see LAHEY, supra note 57, at 2 ("[T] individual model has become a hybrid that resembles the joint or marital model in many regards"); id. at 30 ("Retaining the individual as the tax unit on paper, the Canadian Income Tax Act contains nearly 200 provisions that depend in some way on adult relationships.").

${ }^{85}$ Claire F.L. Young, Taxing Times for Lesbians and Gay Men: Equality at What Cost?, 17 DALhousie L.J. 534, 546 (1994); see Crago, supra note 74, at 5-6.

${ }^{86}$ ITA $\S 122.5$ (goods and services tax rebate); id. $\S \S 122.6-.64$ (Canada child tax benefit); see LAHEY, supra note 57, at 108-09, 113 (describing the operation of the penalty effect of the goods and services tax credit).

${ }^{87}$ ITA $\S \S 40(2)(\mathrm{b}), 54$. 
marital or familial status may increase tax benefits; for example, a taxpayer who is married or in a common-law partnership is allowed a tax credit for support of a spouse or common-law partner. ${ }^{88}$ Spouses and common-law partners may also elect to have one spouse or partner include in income the dividends received from Canadian corporations by the other spouse or partner, if doing so will increase the amount of the credit for the support of spouses and common-law partners. ${ }^{89}$

\section{B. Allocating Expenses}

In terms of the allocation of expenses between spouses and common-law partners, the ITA sometimes permits one spouse or common-law partner to receive an allowance for expenses incurred by, or on behalf of, the other spouse or common-law partner (or even another family member) ${ }^{90}$ For example, the ITA allows certain clergy members a clergy residence deduction, and it allows certain railway workers a deduction for meals and lodging that they provide to a spouse, common-law partner, or a related dependent while they live away from home. ${ }^{91} \mathrm{~A}$ deduction is also allowed for certain business- and education-related moves of the taxpayer and members of the taxpayer's household. ${ }^{92}$ An exemption is allowed for certain fringe benefits (e.g., employer-provided medical and dental insurance and counseling services) provided to persons related to the taxpayer. ${ }^{93}$ Furthermore, a tax credit may be claimed for medical expenses paid for care provided to a spouse, common-law partner, or minor child of the taxpayer. ${ }^{94}$

In some cases, an expense is (or may be) allocated between spouses or common-law partners. For instance, the deduction for child-care expenses is generally allocated to the spouse or common-law partner with lower income. ${ }^{95}$ Permissive allocation exists with regard to several nonrefundable tax credits. For example, apportionment of the adoption expense and child fitness tax credits is left

${ }^{88}$ Id. $\S 118(1)(\mathrm{a})$; see LAHEY, supra note 57 , app. F at 140 (listing income tax subsidies for support of an economically dependent spouse).

${ }^{89}$ ITA $\S 82(3)$.

${ }^{90}$ For a fuller listing of these allowances, see LAHEY, supra note 57, app. G at 141.

${ }^{91}$ ITA $\S 8(1)(\mathrm{c}),(\mathrm{e})$; see also id. $\S 251(2)$ (definition of "related person").

${ }^{92}$ Id. $\S 62$; see also id. § 248(1) (defining "eligible relocation").

${ }^{93}$ Id. $\S 6(1)(\mathrm{a})(\mathrm{iv})$; see also id. § 251(2) (definition of "related person"); LAHEY, supra note 57, at $90 \mathrm{n} .144$ (indicating that the list of excludible fringe benefits "includes extended hospitalization, drug, nursing, dental, optical, or medical care plans; education benefits such as tuition waivers; insurance coverage; employee discounts; survivor benefits; death benefits; employer-financed housing; and low interest or interest-free loans for various purposes").

${ }_{94}$ ITA $\S 118.2$.

95 Id. $\S 63$. For an explanation of this provision, see CAN. REVENUE AGENCY, INFORMATION ABOUT CHILD CARE EXPENSES (2008), available at http://www.craarc.gc.ca/formspubs/prioryear/t778/t778-08e.pdf (explaining how to complete FORM T778, CHILD CARE EXPENSES DEDUCTIONS FOR 2008). 
to the parents. ${ }^{96}$ In addition, the unused portion of certain credits may be transferred from the lower-income spouse or common-law partner to the higherincome spouse or common-law partner. The credits eligible for such a transfer include the unused portion of the child, age, pension, and disability tax credits as well as the unused portion of the tuition, education, and textbook tax credits (with the unused portion of these latter, education-related credits also being eligible for transfer to the taxpayer's parent or grandparent). ${ }^{97}$

\section{Interspousal Transfers of Property}

Marital status may also be relevant in determining a taxpayer's gains on the disposition of capital property. Capital gains have only been subject to tax in Canada since $1972 .{ }^{98}$ At present, a taxpayer's "taxable capital gain" is equal to one-half of the capital gain from the disposition of the property. ${ }^{99}$ The amount of the "capital gain" (or, conversely, "capital loss") is equal to the proceeds of disposition less the sum of (1) the adjusted cost base of the property and (2) selling expenses. ${ }^{100}$ Upon the disposition of personal-use property, the taxpayer's adjusted cost base is deemed to be equal to the greater of $\$ 1,000$ or the taxpayer's actual adjusted cost base, and the taxpayer's proceeds of disposition are deemed to be equal to the greater of $\$ 1,000$ or the actual proceeds of disposition. ${ }^{101}$

${ }^{96}$ ITA $\S \S 118.01(3), .03(3)$.

${ }^{97}$ Id. $\S \S 118.8-.9$.

${ }^{98}$ Daniel Sandler, The Adventure in Venture Capital: Capital Gains vs. Ordinary Income, 42 TAX NOTES INT'L 621, 622-23 (2006) ("Canada's original income tax legislation in 1917 and subsequent income tax acts did not include capital gains and losses until they were specifically added to the tax base in 1972 as part of a major tax reform."). It appears that drawing the line between capital gains and income gains in Canada is as nebulous as drawing the line between capital gains and ordinary income in the United States. See id. at 626 ("Canada . . . does not adequately distinguish between assets held on capital account and those held on business account."); e.g., CAN. REVENUE AGENCY, T4037(E), CAPITAL GAINS 5-6 (2008) available at http://www.cra-arc.gc.ca/formspubs/ prioryear/t4037/t4037-08e.pdf (defining "capital property"); CAN. REVENUE AGENCY, IT-

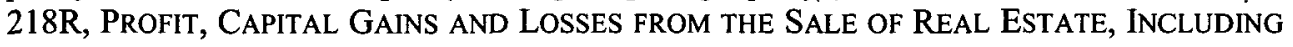
FARMLAND AND INHERITED LAND AND CONVERSION OF REAL ESTATE FROM CAPITAL PROPERTY TO INVENTORY AND VICE VERSA (1986), available at http://www.craarc.gc.ca/E/pub/tp/it218r/it218r-e.html (highlighting the subjective, fact-specific nature of the capital versus income distinction); CAN. REVENUE AGENCY, IT-479R, TRANSACTIONS IN SECURITIES (1984), available at http://www.cra-arc.gc.ca/E/pub/tp/it479r/it479r-e.html (same); CAN. REVENUE AGENCY, IT-459, AdVENTURE OR CONCERN IN THE NATURE OF TRADE (1980), available at http://www.cra-arc.gc.ca/E/pub/tp/it459/it459-e.html (same).

${ }^{99}$ ITA $\S 38(\mathrm{a})$.

${ }^{100} I d . \S 40(1)(\mathrm{a})(\mathrm{i})$.

${ }^{101}$ Id. $\S 46(1)$; see also id. $\S 54$ (defining "personal-use property"). If personal-use property that would ordinarily be disposed of as a set having a fair market value greater than $\$ 1,000$ is "disposed of by more than one disposition so that all of the properties have 
A "disposition" occurs not only when there is a "transaction or event entitling a taxpayer to proceeds of disposition of the property"102 (e.g., a sale of the property, the payment of compensation for the lawful or unlawful taking of the property, or the payment of compensation for the destruction of the property), ${ }^{103}$ but also upon the taxpayer's death or the making of an inter vivos gift. ${ }^{104}$ In the case of gifts, bequests, and inheritances, the proceeds of disposition received by the transferor and the adjusted cost base of the transferee are both deemed to be equal to the fair market value of the transferred property. ${ }^{105}$

The rules for individuals who are not dealing at arm's length (but are not making a gift) are not similarly symmetrical, resulting in a potential tax penalty for engaging in transfers at other than fair market value in such situations. In the case of a disposition for less than fair market value between persons not dealing at arm's length, the proceeds of disposition received by the transferor are deemed to be equal to the fair market value of the transferred property (i.e., more than the actual amount paid), but the adjusted cost base is not similarly adjusted (i.e., it is left at the amount paid by the transferee), resulting in the potential for double taxation. ${ }^{106}$ Conversely, in the case of a disposition for more than fair market value between persons not dealing at arm's length, the adjusted cost base of the transferee is deemed to be equal to the fair market value of the property (i.e., less than the actual amount paid), but the proceeds of disposition received by the transferor are not similarly adjusted (i.e., they are left at the amount paid by the transferee), again resulting in the potential for double taxation. ${ }^{107}$ For this purpose, individuals who are related by blood, marriage, common-law partnership, or adoption are deemed to be related persons not dealing with each other at arm's

been acquired by one person or by a group of persons not dealing with each other at arm's length," then the set of properties is deemed a single item of personal-use property eligible for only a single application of the $\$ 1,000$ minimum cost and $\$ 1,000$ minimum proceeds provision. Id. $\S 46(3)$.

${ }^{102} I d . \S 248(1)$.

${ }^{103} I d . \S 54$.

${ }^{104}$ Id. $\S 69(1)(\mathrm{b})(\mathrm{ii})$ (inter vivos gift); id. $\S 70(5)(\mathrm{a})$ (death).

${ }^{105}$ Id. $\S 69(1)(\mathrm{b})(\mathrm{ii})$ (proceeds of disposition on an inter vivos gift); id. $\S 69(1)(\mathrm{c})$ (cost of transferee upon acquisition by gift, bequest, or inheritance); id. $\S 70(5)$ (a) (proceeds of disposition on death).

${ }^{106} I d$. $\S 54$ (defining "adjusted cost base"); id. § 69(1)(b)(i) (proceeds of disposition on a non-arm's-length disposition for less than fair market value); id. $\S 69(1)$ (c) (deeming the transferee to have acquired the property for its fair market value in the case of gifts, bequests, and inheritances, but making no mention of non-arm's-length transactions).

${ }^{107}$ Id. $\S 54$ (definıng "proceeds of disposition"); id. $\S 69(1)(a)$ (cost of property to transferee); id. $\S 69(1)(b)$ (deeming the proceeds of disposition on a transfer for less than fair market value between persons not dealing at arm's length to be equal to the fair market value of the property transferred, but making no mention of a transfer for more than fair market value in such a situation). 
length. ${ }^{108}$ Whether other, unrelated individuals are dealing with each other at arm's length is a question of fact. ${ }^{109}$

In the case of spouses and common-law partners, an automatic rollover rule applies to effectively (and, as we will see below, electively) defer tax on interspousal transfers of capital property. Such interspousal transfers include transfers incident to the dissolution of the relationship and transfers by reason of the death of one of the spouses or common-law partners. ${ }^{110}$ Interspousal transfers covered by the automatic rollover rule also include transfers to inter vivos or testamentary spousal trusts under the terms of which (1) the spouse or commonlaw partner must be entitled to receive all trust income that arises prior to her death and (2) no person other than the spouse or common-law partner may obtain the use of trust income or capital prior to her death. ${ }^{111}$ This allows the transferor spouse or common-law partner to determine the ultimate beneficiary of the property transferred in trust while still retaining the benefit of the automatic rollover. ${ }^{112}$

Under the automatic rollover rule, the transferor spouse or common-law partner is deemed to have disposed of the property for an amount equal to its adjusted cost base in her hands, and the transferee spouse or common-law partner is deemed to have acquired the property for an amount equal to its adjusted cost base in the hands of the transferor. ${ }^{113}$ Accordingly, under the rollover rule, the

${ }^{108} I d . \S 251(1)(\mathrm{a}),(2)(\mathrm{a})$.

${ }^{109} I d . \S 251$ (c). For guidance on the factors to be taken into account in making this determination, see CAN. REVENUE AGENCY, IT-419R2, MEANING OF ARM's LENGTH ๆ 22-26 (2004), available at http://www.cra-arc.gc.ca/E/pub/tp/it419r2/it419r2-e.html.

${ }^{110}$ ITA $\S 70(6)$ (transfers at death); id. $\S 73(1)-(1.1)$ (inter vivos transfers). For purposes of determining the ownership of community property, the ITA provides that (1) property owned by one of the spouses or common-law partners before it became subject to the community property regime is treated as owned by that spouse and (2) all other property is treated as owned by the spouse or common-law partner who has administration of the property. Id. $\S 248(22)$. If property treated as owned by one spouse or common-law partner prior to the dissolution of the relationship is owned by the other after the dissolution of that relationship, then there is a deemed transfer of the property between the spouses or common-law partners immediately prior to the dissolution of the relationship. $I d$. $\S 248(23)$. In the case of dissolution of the relationship by reason of the death of one of the spouses or common-law partners, then any property transferred or distributed to the surviving spouse or common-law partner is considered to be transferred as a consequence of death. $I d$. $\S 248(23.1)$.

${ }^{111} I d . \S 70(6)$ (transfers at death); id. $\S 73(1)-(1.1)$ (inter vivos transfers).

${ }^{112}$ Brooks, supra note 78 , at 77 . These spousal trusts strongly resemble the qualified terminable interest property (QTIP) trusts that can be created for U.S. federal estate and gift tax purposes. I.R.C. $\S \S 2056(\mathrm{~b})(7), 2523(\mathrm{f})$ (2006). They also suffer from the same infirmities as QTIP trusts. See Brooks, supra note 78, at $77 \mathrm{n} .95$ (describing spousal trusts as analogous to the U.S. QTIP trusts and referring the reader to Wendy Gerzog, The Marital Deduction QTIP Provisions: Illogical and Degrading to Women, 5 UCLA WOMEN's L.J. 301 (1995), for a feminist critique of QTIP trusts).

${ }^{113}$ ITA $\S 70(6)$ (transfers at death); id. $\S 73(1)-(1.1)$ (inter vivos transfers). 
transferor's capital gain on the transfer will be zero, and taxation of the gain will be deferred until the transferee disposes of the property. ${ }^{114}$ Nevertheless, the transferor (or the transferor's executor, in the case of a deceased transferor) may elect out of the automatic rollover rule and have the normal capital gain rules described in the previous paragraph apply to the transaction. ${ }^{115}$

\section{Attribution of Income}

To prevent de facto income splitting, the Canadian tax system "has the most restrictive rules on assignment of income." income to a person with whom she is not dealing at arm's length ${ }^{117}$ will be required to include the assigned amount in her own income, if that amount would have been included in her income had the assignment not been made. ${ }^{118}$ In addition, if a taxpayer directs a payment to be made (or property to be transferred) to another person "for the benefit of the taxpayer or as a benefit that the taxpayer desired to have conferred on the other person," then the taxpayer must include that payment (or property) in her own income to the extent that it would have been so included had the payment (or transfer of property) been made directly to her. ${ }^{119}$

Income or loss from property that a taxpayer transferred or loaned (directly or indirectly) to her spouse or common-law partner (or to someone who later became her spouse or common-law partner) is attributed back to the taxpayer. ${ }^{120}$ This rule applies equally to property substituted for the property transferred or loaned by the taxpayer. ${ }^{121}$ Similar rules apply to income or loss from property that a taxpayer

${ }^{114}$ In the case of a transfer of a wholly owned principal residence from one spouse or common-law partner to another to which the automatic rollover rule applies, the exclusion for gain on the disposition of a principal residence is applied as if (1) the transferee had owned the property during the time that it was owned by the transferor and (2) the transferee had used the property as a principal residence during the period that the transferor so used it. Id. $\S 40(4)$.

${ }_{115} I d . \S 70(6.2)$ (transfers at death); id. $\S 73(1)$ (inter vivos transfers).

${ }^{116}$ AULT ET AL., supra note 62, at 267.

${ }^{117}$ See supra notes 108-09 and accompanying text.

${ }^{118}$ ITA $\S 56(4)$.

${ }^{119}$ Id. $\S 56(2)$.

${ }^{120} I d$. $\$ 74.1(1)$.

${ }^{121} I d$. This rule does not, however, apply to income from property purchased with income attributed to the taxpayer. As the Canada Revenue Agency explains:

Income or loss derived from the investment or other use of the income from transferred property is not attributed to the transferor and thus for income tax purposes is income or loss of the transferee. For example, interest on any interest allowed to accumulate is not attributed to the transferor and is income of the transferee. 
transferred or loaned (directly or indirectly) to a minor who either does not deal with the taxpayer at arm's length ${ }^{122}$ or is the taxpayer's niece or nephew. ${ }^{123}$

Capital gains and losses from the disposition of property that a taxpayer transferred or loaned (directly or indirectly) to her spouse or common-law partner (or to someone who later became her spouse or common-law partner) are attributed back to the taxpayer. ${ }^{24}$ This rule applies equally to property substituted for the property transferred or loaned by the taxpayer, resulting in the attribution to the taxpayer of capital gains and losses on the disposition of the substituted property. ${ }^{125}$ Similar rules generally do not, however, apply to transfers or loans of property to minors. ${ }^{126}$

These income/loss and capital gain/loss attribution rules are buttressed with antiavoidance rules. Accordingly, a taxpayer cannot circumvent these attribution rules through the interposition of a trust, the use of back-to-back loan arrangements or loan guarantees involving third parties, or the repayment of existing indebtedness with property that the taxpayer has transferred or loaned. ${ }^{127}$ Furthermore, where an interest-free or low-interest loan is made between individuals not dealing at arm's length (regardless of age), then the income from the loaned property, from property acquired with the loaned property, or property substituted for such property is attributed to the lender if "one of the main reasons for making the loan or incurring the indebtedness was to reduce or avoid tax."128

Yet, there are exceptions to the application of these attribution rules. The attribution rules do not apply to property that the taxpayer has transferred (or to property substituted for transferred property) if the fair market value of the property transferred equals the fair market value of the property received in exchange. ${ }^{129}$ If the consideration received upon such a transfer includes debt, then the exception from the attribution rules will not apply unless (1) the interest charged on the debt at least equals the lesser of a prescribed interest rate or an

CAN. REVENUE AgENCY, IT-511R, INTERSPOUSAL AND CERTAIN OTHER TRANSFERS AND LOANS OF PROPERTY $\mid 6$ (1994), available at http://www.cra-arc.gc.ca/E/pub/tp/it51 r r/it $511 \mathrm{r}$-e.html. Thus, so-called second-generation income is exempt from attribution.

${ }^{122}$ See supra notes $108-09$ and accompanying text.

${ }^{123}$ ITA $\S 74.1(2)$.

${ }^{124} \mathrm{Id}$. $\$ 74.2(1)$.

125 See id. $\$ 248(1)$, (5) (defining "property" and "substituted property"); CAN. REVENUE AGENCY, IT-511R, supra note 121, ๆ 27 (explaining the rule and providing an example where capital gains from the disposition of substituted property were attributed to the taxpayer who initially transferred the property).

126 See CAN. Revenue AGENCY, IT-511R, supra note 121, 99 3-4 (making no mention of transfers or loans to anyone other than spouses and common-law partners); $c f$. ITA $\S 75.1$ (applying such rules in the context of transfers of interests in family farms or fishing businesses).
${ }^{127}$ ITA $\S \S 74.1(3), 74.5(6),(7),(9)$
${ }^{128} I d . \S 56(4.1)-(4.3)$.
${ }^{129} I d . \S 74.5(1)(\mathrm{a})$. 
arm's-length interest rate and (2) the interest is paid within 30 days of the close of every taxable year. ${ }^{130}$ In the case of a fair market value transfer of property to a taxpayer's spouse or common-law partner, the taxpayer cannot qualify for the exception from the attribution rules unless the taxpayer elects out of the application of the automatic rollover rules (discussed above).

Similarly, the attribution rules will not apply to property that the taxpayer has loaned (or property substituted for loaned property) if (1) the taxpayer charges interest on the loan at a rate that at least equals the lesser of a prescribed interest rate or an arm's-length interest rate and (2) the interest is paid within 30 days of the close of every taxable year. ${ }^{132}$ There is also an exception from the attribution rules in the case of married taxpayers or taxpayers in a common-law partnership who live separate and apart from each other because of the breakdown of their relationship. ${ }^{133}$

\section{E. Permitted Income Splitting}

Notwithstanding this elaborate set of attribution rules, the ITA does permit a certain amount of de jure income splitting to spouses and common-law partners. ${ }^{134}$ For instance, support payments made by one spouse or common-law partner to the other while living separate and apart because of the breakdown of their relationship are deductible by the payer and includible in the income of the payee. ${ }^{135}$ In addition, one spouse or common-law partner may make deductible contributions to a registered retirement savings plan for the other spouse or common-law partner, who will then be taxed (possibly at a lower marginal rate) on payments from the plan. ${ }^{136}$ And, more recently, spouses and common-law partners have been given the option of electing to split pension income for tax purposes. ${ }^{137}$

${ }^{130} \mathrm{Id} . \S 74.5(1)(\mathrm{b})$

${ }^{131} I d . \S 74.5(1)(\mathrm{c})$. For a discussion of the automatic rollover rules, see supra text accompanying notes $113-15$.

${ }^{132}$ Id. $\S 74.5(2)$.

${ }^{133}$ Id. $\$ 74.5(3)$.

${ }^{134}$ Lisa Philipps, Income Splitting and Gender Equality: The Case for Incentivizing Intra-Household Wealth Transfers, in CHALLENGING GENDER INEQUALITY IN TAX POLICY Making: Comparative PERSPeCtives (Kimberley Brooks et al. eds., forthcoming) (manuscript at 4-7) (on file with author).

${ }^{135}$ ITA $\S \S 56(1)(\mathrm{b}), 56.1,60(\mathrm{~b})$. In contrast, child support payments are neither deductible by the payer nor includible in the income of the payee. Id. $\S \S 56(1)(\mathrm{b}), 56.1$, 60(b).

${ }^{136}$ Id. $\S \S 74.5(12)($ a), 146(5.1); see LAHEY, supra note 57, app. G (listing income tax provisions that allow spouses to split incomes and transfer deductions between themselves as well as listing provisions that shelter benefits provided to a spouse from taxation).

${ }^{137}$ ITA $\S 60.03$. 
In addition, in Neuman v. Minister of National Revenue, the Supreme Court of Canada approved of "dividend sprinkling." 138 In Neuman, the taxpayer had created a holding company to which he transferred shares of stock that he owned in another company. ${ }^{139} \mathrm{He}$ received shares of one class of the holding company's stock in exchange for this contribution of operating company stock. ${ }^{140}$ The taxpayer's wife then contributed cash for shares of another class of the holding company's stock. ${ }^{141}$ The taxpayer's wife became the sole director of the holding company and, in that capacity, had discretion in paying dividends on these two classes of stock. ${ }^{142}$ After the holding company received a dividend from the operating company, the taxpayer's wife declared a dividend of $\$ 5,000$ on her husband's stock and a dividend of $\$ 14,800$ on her own stock, effectively splitting the income from the operating company between the two of them. ${ }^{143}$ (It is worth noting that the taxpayer's wife promptly lent the $\$ 14,800$ dividend that she received to her husband-a loan that he had not repaid prior to her death some six years later. ${ }^{144}$ ) The Supreme Court of Canada held that this income-splitting arrangement would be respected for tax purposes. ${ }^{145}$ Following this decision, the ITA was amended to curtail dividend sprinkling to minors, but the Supreme Court of Canada's decision in Neuman was otherwise left intact. ${ }^{146}$

\section{-F. Attribution of Ownership}

At times, marital status can be relevant to the determination of the ownership of property or control of entities. For example, a taxpayer is denied a deduction for a "superficial" loss, which combines elements of the U.S. "wash sale" rules and the loss disallowance rules in $\S \S 267$ and 1041 of the U.S. Internal Revenue Code. ${ }^{147}$ Akin to a wash sale, a "superficial" loss occurs when a taxpayer disposes of property at a loss and then the taxpayer or an "affiliated" person reacquires that same property-or property identical to it-within a short time frame. ${ }^{148}$ For this purpose, spouses and common-law partners are the only individuals who are

${ }^{138}$ [1998] 1 S.C.R. 770 (Can.); see generally David G. Duff, Neuman and Beyond: Income Splitting, Tax Avoidance, and Statutory Interpretation in the Supreme Court of Canada, 32 CAN. Bus. L.J. 345 (1999).

${ }^{139}$ Neuman, [1998] 1 S.C.R. 770, paras. 3, 5.

${ }^{140} \mathrm{Id}$. para. 5.

${ }^{141} I d$.

${ }^{142} I d$. para. 6.

${ }^{143}$ Id. para. 7.

${ }^{144} I d$. para. 8.

${ }^{145}$ Id. para. 65.

${ }^{146}$ ITA $\S 120.4$.

${ }^{147}$ Id. $\S 40(2)(\mathrm{g})(\mathrm{i})$. For the U.S. wash sale rules; see I.R.C. $\S 1091$ (2006). Where $\S$ 267 and $\S 1041$ overlap, $\S 1041$ takes precedence. $I d . \S 267(\mathrm{~g})$.

${ }^{148}$ ITA $§ 54$. 
deemed to be "affiliated" persons. ${ }^{149}$ Thus, the acquisition of identical property by the taxpayer's spouse or common-law partner is attributed to the taxpayer and treated as if the taxpayer had acquired the substituted property himself. More broadly, through its application to the acquisition of the "same" property, the superficial loss rule also operates to disallow capital losses on the transfer of property from one spouse or common-law partner to the other, as do $\S \S 267$ and 1041 in the U.S. federal income tax.

Furthermore, in determining whether an individual and a corporation are "affiliated" with each other, the ownership of spouses and common-law partners is aggregated and tested together to determine whether this "affiliated group of persons" is in control of the corporation. ${ }^{150}$ If the spouses or common-law partners are in control of the corporation, this may result in the denial of a deduction for a capital loss resulting from the redemption of one of the spouse's or common-law partner's stock in the corporation. ${ }^{151}$

\section{G. "Beyond Conjugality"}

In 2001, the Law Commission of Canada issued a report titled Beyond Conjugality: Recognizing and Supporting Close Personal Adult Relationships. ${ }^{152}$ In that report, the Law Commission recommended a wide-ranging reconsideration of the role of relationships in Canadian law. As the Law Commission put it, "It is time to try to imagine a legislative regime that more effectively accomplishes its goals by relying less on whether people are living in particular kinds of relationships." 153

To achieve this end, the Law Commission proposed that a new methodology be adopted "for assessing any existing or proposed law that employs relational terms to accomplish its objectives." 154 This methodology consists of a four-step analysis:

First Question: Are the objectives of the law legitimate?

If not, should the law be repealed or fundamentally revised?

Second Question: Do relationships matter?

If the law's objectives are sound, are the relationships included in the law important or relevant to the law's objectives?

${ }^{149} I d . \S 251.1(1)$.

${ }^{150} I d . \S 251.1(1)(\mathrm{b}),(3)$.

${ }^{151}$ Id. § 40(3.6).

152 BEYOND CONJUGALITY, supra note 66. In 2006, the conservative government of Prime Minister Stephen Harper eliminated funding for the Law Commission of Canada, effectively shuttering the commission. Steven Chase, Ottawa's \$2-Billion Hit List, THE GloBE \& MAIL (Toronto, Canada), Sept. 26, 2006, at A1; John Ibbitson, Fatal Cuts to Law Panel Deeply Ideological, THE GLOBE \& MAIL (Toronto, Canada), Sept. 28, 2006, at A4.

${ }^{153}$ BEYOND CONJUGALITY, supra note 66 , at xii.

${ }^{154} \mathrm{Id}$. 
Third Question: If relationships matter, can individuals be permitted to designate the relevant relationships themselves?

Could the law allow individuals to choose which of their close personal relationships they want to be subject to the particular law?

Fourth Question: If relationships matter, and self-designation is not feasible or appropriate, is there a better way to include relationships?

If relationships do matter, and public policy requires that the law delineate the relevant relationships to which it applies, can the law be revised to more accurately capture the relevant range of relationships? ${ }^{155}$

After describing its methodology, the Law Commission applied the methodology to a series of different areas of Canadian law, including marine liability, employment, immigration, evidence, bankruptcy, banking, and pensions.

The Law Commission devoted a lengthy section of its report to an evaluation of aspects of the Income Tax Act. ${ }^{156}$ The Law Commission first revisited the debate over individual versus joint filing and concluded that individual filing was both preferable and more consistent with its law reform project. ${ }^{157}$ The Law Commission then turned to an examination of several specific ITA provisions using the methodology described above. It is worth reviewing parts of the Law Commission's evaluation of specific ITA provisions to obtain a sense of how its methodology applies in the tax context. Thus, by way of example, I summarize below the Law Commission's evaluation of (1) three dependent care credits, (2) the credit for support of a low-income spouse or common-law partner, and (3) the automatic rollover rule that applies to interspousal transfers of capital property.

\section{Dependent Care Credits}

The ITA contains three separate credits for the care of individuals who are dependent on the taxpayer by reason of age or disability. ${ }^{158}$ Each of these credits has its own particular requirements; nevertheless, each credit requires that the dependent individual be in some way related to the taxpayer. In answering its first question, the Law Commission noted that each credit is intended to reflect that taxpayers supporting individuals who are dependent upon them by reason of age or

${ }^{155} I d$. at xii-xiii. For a more detailed description of the analysis required by each of these questions, see $i d$. at $30-36$.

${ }_{156} I d$. at $63-89$.

${ }^{157} I d$. at 71 ("In summary, our tax system is and should continue to be premised on the individual as the basic unit of taxation. Family-based taxation is not consistent with the control theory underlying Canada's income tax, nor is it consistent with the empirical evidence demonstrating the unpredictable degree of income sharing in families. Individual taxation is consistent with the control theory and has the advantages of administrative simplicity and neutrality regarding personal relationships.").

${ }^{158}$ ITA $\S 118(1)$ (b) (wholly dependent person credit); id. $\S 118(1)(c .1)$ (in-home care of relative credit); id. $\S 118(1)$ (d) (dependents credit). 
disability have a reduced ability to pay taxes. ${ }^{159}$ In addition, these credits "provide income support to families supporting and caring for relatives unable to support themselves." 160 Upon reflection, the Law Commission concluded that both of these objectives are legitimate, and it further concluded, in answer to its second question, that relationships are relevant to these objectives. ${ }^{161}$ In answer to its third question, the Law Commission maintained that relying on taxpayers to identify those dependency relationships that reduce their ability to pay tax "may not be feasible since the potential for abuse is too great." 162 Finally, in answer to its fourth question, the Law Commission found that

the Income Tax Act could be revised to more accurately capture the relevant range of dependency relationships .... There is no justification for limiting entitlement to these credits to persons with dependants who are relatives, or to dependants with whom a taxpayer lives. Taxpayers who support dependents-whether related or not, whether living in the same household or not, whether wholly or partially dependent-should be entitled to claim the tax credits because the provision of support itself reduces the resources they have available to meet their tax obligations. The credit should be available to taxpayers who have provided financial support or unpaid caregiving to a person who is dependent by reason of age, disability or illness. ${ }^{163}$

\section{Credit for Support of a Spouse or Common-Law Partner}

The Law Commission also considered the credit for support of a dependent spouse or common-law partner. ${ }^{164}$ The Law Commission concluded that this credit fails to serve a legitimate objective and, therefore, does not make it past the first part of its four-part methodology. ${ }^{165}$ The Law Commission based this conclusion on the credit's promotion of economic dependency within conjugal relationships, which "offends against the principle that government should be neutral with respect to the roles assumed within personal relationships." Commission pointed out that the dependency requirement and income limits had been lifted from the credit during World War II in order to encourage women to enter the workforce to support the war effort; they were then reinstated after the war to encourage women to return to the home in order to free up jobs for

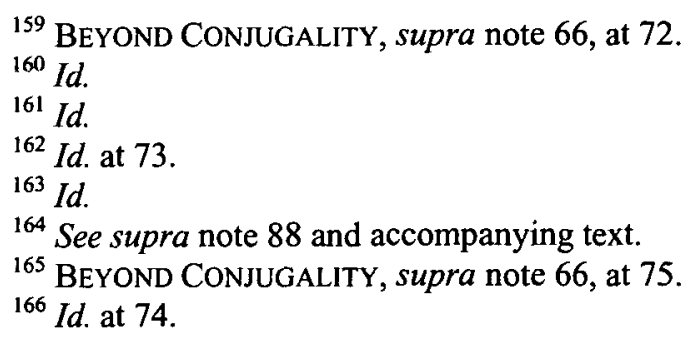


returning servicemen. ${ }^{167}$ The Law Commission also observed that the credit "is claimed disproportionately by relatively well-off individuals. This should not be surprising. Generally, middle- and high-income individuals are more able to afford to support an economically dependent spouse." noted that, far from reducing the ability to pay tax, the household services that the dependent spouse or common-law partner provides to the taxpayer may actually increase the ability to pay tax by reducing the services that the taxpayer must purchase in the marketplace. ${ }^{169}$ Finally, the Law Commission rejected the justification that the credit "provides income support to those families in which one spouse is looking after children in the home or acting as a caregiver for elderly parents." ${ }^{170}$ If this is the purpose of the credit, the Law Commission explained, then the credit is overinclusive because more than one-half of taxpayers claiming the credit are not supporting children and "[i]t is impossible to determine in how many of these cases the dependent spouse is providing care to individuals other than children." ${ }^{\text {"171 }}$ Ultimately, the Law Commission concluded that, "[b]ecause its primary objective appears to be to promote dependency in personal relationships, the spouse and common-law partner credit should be repealed."

\section{Automatic Rollover Rule}

With regard to the automatic rollover rule for interspousal transfers of capital property, ${ }^{173}$ the Law Commission answered its first question by concluding that it serves legitimate objectives. The Law Commission found that the rollover rule serves legitimate administrative objectives because (1) shifts of legal title within conjugal couples do not necessarily reflect shifts in beneficial ownership, (2) tracing the funds used to acquire property would be difficult, (3) transactions between spouses and common-law partners often take place on an informal basis without an understanding of the tax consequences, and (4) taxation of interspousal property transfers would raise liquidity problems as the couple would have to find the funds to pay the tax. ${ }^{174}$ Accordingly, "[t]axing the transfers of capital property within conjugal relationships would be too costly and intrusive to administer."175 The Law Commission additionally found that the rollover rule "serves the social policy objective of encouraging, or at least not discouraging, the redistribution of property within personal relationships."176

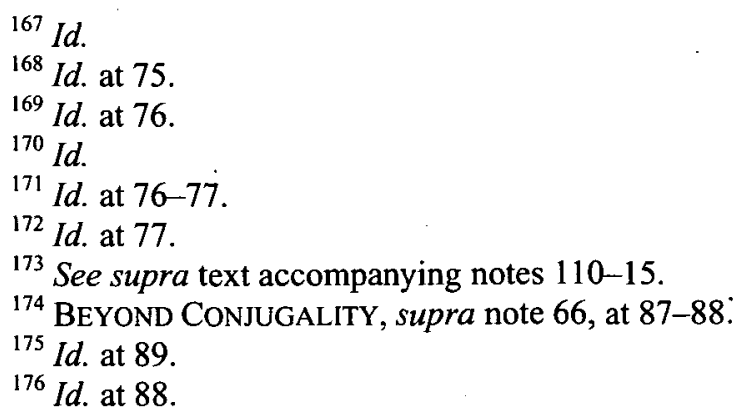


Having answered its first question affirmatively, the Law Commission similarly answered its second question when it stated that "[ $[$ ] he entangled kinds of economic interdependencies that characterize close personal relationships are the very raison d'être of the rollover rules." ${ }^{177}$ The Law Commission then summarily answered its third question negatively when it asserted that "[s]elf-selection of the appropriate range of relationships is obviously not a feasible option." 178 (At this juncture, it is worth noting that I take strong issue with this unexplained and uninterrogated conclusion in developing my own proposal below.) Finally; in answer to its fourth question, the Law Commission recommended that the rollover provision be revised to more accurately capture the relevant range of relationships by being made applicable "to any relationship between persons living together in economically interdependent relationships." 179

Having now been given a flavor of the Canadian individual income tax system as well as a glimpse of the Law Commission's view of how that tax system might be altered to move "beyond conjugality" and toward the recognition (where relevant) of the broad range of relationships that actually exist in society, we can now turn to formulating a proposal for such a system that fits the U.S. tax environment.

\section{DESIGNING AN INCLUSIVE U.S. INDIVIDUAL TAX FILING SYSTEM}

\section{A. Background}

In building an individual tax filing system that is more inclusive and flexible, the focus will be on achieving a balance between, as Julie Nelson has put it, "individuation" and "relation." 180 The proposal set forth below relies upon a conception of people "as differentiated individuals who are also interdependent and connected." 181 Thus, at certain points the focus will be on the taxpayer as an

${ }^{177} I d$. at 89 .

${ }^{178} I d$.

${ }^{179} \mathrm{Id}$.

${ }^{180}$ Julie A. Nelson, Feminism, OBJECTIVITY AND ECONOMiCs 16 (1996).

${ }^{181}$ Id. As Nelson explains later in the context of rethinking the taxable unit from a feminist perspective:

[I]solation and engulfment form the "negative complementarity" of the separation/connection dualism. The positive aspect of separation is the definition of individual identity; but taken too far, that is, unbalanced by a recognition of necessary social connections, the myth of the isolated, completely independent unit rears its head. The positive aspect of connection is the recognition of relationship to others; but taken too far, that is, unbalanced by a recognition of individuality, a person is engulfed (as in coverture) within the definition of the other. The negative complementarity of isolation and engulfment should be 
individual while at other points it will be on accommodating the economically interdependent relationships that the individual has entered into.

Before proceeding further, it is worth taking a moment to explain the focus here on the economically interdependent relationships that individuals enter into, Naturally, individuals also enter into other types of relationships (e.g., familial, social, or emotional), and they sometimes enter into relationships with multiple dimensions (e.g., a relationship that is familial, emotional, and economic). But, in its application, the income tax is predominantly concerned with the economic aspects of the relationships that we enter into. ${ }^{182}$ For this reason, the income tax is best suited to supporting or accommodating (or, at the very least, to refraining from interfering with) the economic aspects of relationships. It might be helpful to recall at this point the simple example that I gave in the introduction to this Article: While the income tax is well suited to providing incentives for the equal sharing of financial resources within families, it is not well suited to fostering an atmosphere of mutual respect within families or to deterring domestic violence.

When accommodating relationships in the tax laws, it is necessary to keep the purpose and scope of the tax laws in mind. As the Law Commission of Canada has explained:

Since laws have different objectives, it follows that the definition of the relevant relationships should differ as we move from one law to another. For example, economic dependence or interdependence is the most important relational attribute for purposes of a law that seeks to respond to the economic consequences of the breakdown of a relationship. Emotional intimacy is the most important relational attribute to be considered by a law that seeks to protect the value of trust and candour in intimate relationships. Relational definitions that do not focus on the relevant factual attributes of relationships will miss their mark,

replaced by the positive complementarity of individuation and relation. Persons are conceived as individuals in relation.

Id. at 99 . To implement this notion of individuals in relation, Nelson proposes the adoption of the "individual earner plus his or her dependents" as a quasi-taxable unit. Id. at 110 . The income of the individuals comprising this quasi-taxable unit would not be aggregated, but the individual earner would be allowed a deduction for his or her dependents, a class of persons that would be limited to those unable to support themselves by reason of age (whether young or old) or disability. Id. Nelson's conception of the individual in relation to others is strongly influenced by the hegemony of the traditional family, see id. at 110-12, and, consequently, is not as broad as the view taken in this Article of the individual in relation to others.

${ }^{182}$ For an argument that noneconomic factors should be taken into account in assessing the fairness of a tax, see generally. Infanti, supra note 13, and Infanti, Taxing Civil Rights Gains, supra note 1. See also supra note 13 (discussing how the focus of this Article is consistent with that approach). 
excluding some relationships that ought to be included, and including some relationships that ought to be excluded. Thus, carefully tailoring relational definitions to the objectives of particular laws will eliminate inequalities and enable laws to accomplish their objectives more effectively. ${ }^{183}$

It is thus no wonder that the Law Commission's recommendation for reform of the Canadian automatic rollover rule targeted "persons living together in economically interdependent relationships," 184 while its recommendations for reform in other areas of the law were not so limited.

The justifications proffered for treating married different-sex couples as a taxable unit provide further evidence that economic interdependence is the most important relational attribute for purposes of the tax laws. ${ }^{185}$ As discussed above, these justifications principally rely upon the couple's presumed sharing of financial resources and their acting as a single economic unit. ${ }^{186}$ The justifications proffered for various antiabuse rules likewise focus on economic interdependence. For example, the U.S. Supreme Court identified the common thread running through I.R.C. $\S 267$ as an economic one:

[The predecessor of $\S 267$ ] states an absolute prohibition-not a presumption-against the allowance of losses on any sales between the members of certain designated groups. The one common characteristic of these groups is that their members, although distinct legal entities, generally have a near-identity of economic interest. It is a fair inference that even legally genuine intra-group transfers were not thought to result, usually, in economically genuine realizations of loss, and accordingly that Congress did not deem them to be appropriate occasions for the allowance of deductions. ${ }^{187}$

${ }^{183}$ BEYOND CONJUGALITY, supra note 66 , at 36.

184 See id. at 89 (emphasis added). For a discussion of the Canadian automatic rollover rule, see supra Part III.G.3.

${ }^{185}$ Consequently, commentators who argue for equal treatment of same-sex couples under the tax laws tend to pick up this argument and rely on it as well. See, e.g., Patricia A. Cain, Same-Sex Couples and the Federal Tax Laws, 1 LAW \& SEXUALITY REV. 97, 130-31 (1991) ("If joint returns are the appropriate reporting device for husband and wife, then I believe joint returns should be available for same-sex couples who consider themselves just as committed as married couples and whose household is just as much a single economic unit.").

${ }^{186}$ H.R. REP. No. 98-432, at 1491 (1984); Michael J. McIntyre, Marital Income Splitting in the Modern World: Lessons for Australia from the American Experience, in TAX UNITS AND THE TAX RATE SCALE, supra note 78, at 1, 2-4; see also supra Part II.B.

${ }^{187}$ McWilliams v. Comm'r, 331 U.S. 694, 699 (1947) (footnote omitted). 
Similarly, the Section on Taxation of the American Bar Association submitted this critique of the constructive ownership rules in $\S 318$ while Congress was considering their enactment:

[Section 318] assumes a unity of action and of interest within the family which is frequently lacking, at least where dependency does not exist. It has been suggested, therefore, that the family should be limited to one's minor children, spouse and other dependants. It is the experience of practicing lawyers that one is consulted far more often with respect to family and partnership squabbles over property than on family plans to avoid income taxes. ${ }^{188}$

The Section on Taxation's critique of $\S 318$ is particularly insightful. It not only draws attention to the fundamental underpinning of the constructive ownership rules - that is, the desire to amalgamate the ownership of those united by common economic interests-but it also underscores how often these rules miss their mark in practice. ${ }^{189}$ Harking back to our earlier discussion of joint versus individual filing, ${ }^{190}$ the problem with the current related party antiabuse rules is that their drafters have counterfactually assumed that economic interdependence is either usually or always an attribute of certain noneconomic relationships (e.g., marital and familial relationships). As the Law Commission of Canada so presciently warned, this assumption has resulted in the establishment of rules that are both overinclusive (i.e., capturing some relationships that lack economic interdependence) and underinclusive (i.e., failing to capture other relationships that are marked by economic interdepedence). The task to which we now turn is to rectify this error by identifying other, more accurate markers for economic interdependence - the relational attribute that is most relevant to the application of the tax laws.

\section{B. Transfers of Property}

\section{Background}

In its reexamination of the automatic rollover rule, the Law Commission of Canada summarily rejected the idea of allowing taxpayers the freedom to identify their own economically interdependent relationships because it would "obviously" not be "feasible" to allow individuals to determine when the rollover rule will

${ }^{188}$ Metzger Trust v. Comm'r, 76 T.C. 42, 56-57 (1981).

189 BORIS I. BITTKER \& JAMES S. Eustice, FEDERAL INCOME TAXATION OF CORPORATIONS AND SHAREHOLDERS I 9.02[2] \& n.49 (2000) (discussing attempts by taxpayers to avoid the application of the $\S 318$ constructive ownership rules by demonstrating hostility among the relevant family members).

${ }^{190}$ See supra Part II.D. 
apply. ${ }^{191}$ I disagree with the Law Commission's assessment. Not only is it feasible to allow taxpayers to identify their own economically interdependent relationships, but asking taxpayers to do so in the context of property transfers will actually serve as the cornerstone for my proposal for an inclusive U.S. individual filing regimea filing regime that accommodates not only the conjugal relationships that individuals enter into, but all of the economically interdependent relationships that taxpayers enter into (e.g., with parents, children, relatives, or friends). For this reason, we will begin by considering how transfers of property between economically interdependent persons should be treated for tax purposes. We will then build on that discussion by considering related questions regarding attribution of ownership and other antiabuse rules; attribution of income; allocation of expenses; and, finally, the need to reform other provisions in the tax laws that take relationships into account.

Let us begin by answering the first two questions posed by the Law Commission: "Are the objectives of the law legitimate?" and "Do relationships matter?" ${ }^{\prime 192}$ Obviously, it is legitimate for an income tax to take account of-and tax-transfers of property. The more important question of these two is whether relationships are relevant to the taxation of property transfers. The answer to this question is that relationships are relevant to the taxation of property transfers. Indeed, the Law Commission's reexamination of the Canadian automatic rollover rule indicates that the tax system should refrain from interfering with transfers of property within certain (namely, economically interdependent) relationships. Recall that the Law Commission found that the automatic rollover rule serves legitimate administrative objectives because (1) shifts of legal title within conjugal couples do not necessarily reflect shifts in beneficial ownership, (2) tracing the funds used to acquire property can be difficult, (3) transactions between spouses and common-law partners often take place on an informal basis without an understanding of the tax consequences, and (4) taxing interspousal property transfers would raise liquidity problems as the couple would have to find the funds to pay the tax. ${ }^{193}$ Much of this reasoning can be applied equally to transfers of

191 See supra note 178 and accompanying text.

${ }^{192}$ See supra note 155 and accompanying text.

${ }^{193}$ See supra text accompanying notes 174-76; see also Dulude, supra note 59 , at 104-05 (making this point with regard to property transfers within families).

One person's neutrality may, however, be another's invitation for tax avoidance. Stephanie McMahon has recently argued against individual filing on the ground that it would introduce untold complexity into the administration of the tax laws because it would give rise to a return of pre-1948 tax avoidance schemes where property was transferred between spouses solely for tax avoidance reasons. McMahon, supra note 2, at 8-49. This argument is unpersuasive for a number of reasons. First, it overlooks the successful implementation of individual tax filing regimes by other countries. Second, it perpetuates the hegemony of the traditional family by disregarding the import of transfers outside of the context of the marital unit (even expanded to include same-sex couples who have entered into a relationship that is legally recognized under state law). Third, it discounts the 
property in the context of other conjugal-as well as nonconjugal-economically interdependent relationships. Accordingly, the Law Commission's reasoning provides support for the position that we should refrain from taxing transfers of property between economically interdependent persons.

The U.S. tax system already embraces this idea that the tax system should be neutral with regard to transfers of property within economically interdependent relationships, albeit in a limited and biased fashion. Sections 1041, 2056, and 2523 of the Internal Revenue Code allow husbands and wives to transfer property to each other free of income, estate, and gift tax. As I have argued elsewhere, these provisions - especially when taken together with the income-splitting privilege afforded by the joint return ${ }^{194}$-make tax a neutral factor when spouses (presumed to be acting as a single economic unit) decide whether-and, if so, how-to divide their income and property between them. ${ }^{195}$ It also affords married different-sex couples a certain zone of privacy because the Internal Revenue Service has no reason to inquire into nontaxable events on audit. ${ }^{196}$ Moreover, even moving beyond the confines of the married different-sex couple to other family members

real import of shifting legal title within the marital unit, given the ease and prevalence of divorce nowadays. See Marjorie E. Kornhauser, Theory Versus Reality: The Partnership Model of Marriage in Family and Income Tax Law, 69 TEMP. L. REV. 1413, 1443 (1996) ("Yet, to a large extent, title really does matter, especially given the high divorce rate."); Philipps, supra note 134, at 15-16 (explaining that having legal title is important to divorcing women in Canada-notwithstanding the existence of a property equalization regime there--because of women's possible "lack of access to costly legal advice or to courts in order to establish or enforce a claim; the difficulty of tracing assets that may be owned outside the country; pressures to trade child custody for a lesser share of property; and the exclusion of some intangibles like professional degrees and licenses from what is considered divisible property; and the legal uncertainty surrounding others such as unvested pension plan rights"). Fourth, this argument discounts the agency of women within the marital unit. See id. at 12-13. Fifth, it ignores the fact that the income-splitting joint return amounts to nothing less than legislatively sanctioned tax avoidance. Through the joint return, a married owner of property can minimize his taxes by splitting the income from property without actually parting with control over that property. In contrast, unmarried taxpayers can achieve such a splitting of income only by actually parting with control over their property. Finally, this argument overlooks the fact that adopting the married different-sex couple as the taxable unit has in no way ended attempts by husbands and wives to manipulate tax rules to their advantage-quite the contrary, it has actually spawned new opportunities for such manipulation. See I.R.C. $\S 71(f)$ (2006) (alimony frontloading rules); id. $\S 2056$ (b) (terminable interest rules); id. $\S 2523$ (b) (same); id. $\S$ 2056(d) (no marital deduction where surviving spouse is a nonresident alien); id. $\S 2523$ (i) (same), along with each and every provision in the Internal Revenue Code that applies the related party rules of $\S \S 267$ and 318 , which attribute the ownership of property from one spouse to the other.

${ }^{194}$ I.R.C. $\S 6013$.

${ }^{195}$ Anthony C. Infanti, Bringing Sexual Orientation and Gender Identity into the Tax Classroom, 59 J. LEGAL EDUC. 3, 21-33 (2009).

${ }^{196} \mathrm{Id}$. 
(who are presumed to have economic ties with each other), the realization requirement in the U.S. federal income tax has been interpreted in such a way that neither a gift nor a bequest is a taxable event to the transferor, ${ }^{197}$ and, by statute, the recipient of a gift or bequest is not required to include that gift or bequest in her gross income. ${ }^{198}$ The estate and gift taxes may impose a hefty levy on such transfers; however, in the context of the traditional family, ${ }^{199}$ these taxes only apply to an exceedingly small slice of very wealthy transferors, ${ }^{200}$ who can still benefit from special rules that look to the existence of familial relationships when either reducing or deferring tax. ${ }^{201}$ As a result, the income, estate, and gift tax rules permit the shifting of substantial amounts of property within most nuclear and extended traditional families free of concerns about federal taxes.

These rules do not, however, render tax a neutral factor in the shifting of property among the members of nontraditional families. For the nontraditional family, it is clear that the benefits of $\S \S 1041,2056$, and 2523 are off limits because, by their terms, these provisions apply only to transfers between husbands and wives. ${ }^{202}$ Furthermore, as described in the following paragraphs, the application of other beneficial tax rules concerning gifts and bequests are subject to significant interpretational issues and doubt when applied to nontraditional families.

1972 Boris I. BittKer \& LAWrence LoKken, Fepderal TaXation of InCOME, ESTATES, AND GIFTS $\uparrow 40.3$ (3d ed. 2000).

${ }^{198}$ I.R.C. $\S 102$.

${ }^{199}$ See Infanti, Sodomy Statute, supra note 1, at 785-87 (discussing how the gift tax might apply very differently-and detrimentally-to a same-sex couple or even an unmarried different-sex couple).

${ }^{200}$ I.R.C. $\$ 2010$ (unified credit permitting decedents dying in 2009 to transfer $\$ 3.5$ million worth of property-including certain lifetime gifts-free of estate tax); id. $\S$ 2503(b) (gift tax annual exclusion); id. $\S 2505$ (unified credit permitting each taxpayer to transfer $\$ 1$ million worth of property free of gift tax); Rev. Proc. 2008-66, $\$ 3.30,2008-2$ C.B. 1107 (setting the gift tax annual exclusion at \$13,000 for 2009); see CITIZENS FOR Tax Justice, Latest State-By-State Data Show Why Obama Should SCale Back His Proposal to CUT THE FEDERAL EsTATE TAX 1 (2008), available at http://www.ctj.org/pdf/estatetax20081203.pdf (indicating that "only 0.7 percent of deaths in 2006 resulted in estate tax liability in 2007"). It is worth noting that, due to congressional inaction, the estate tax was repealed with respect to decedents dying on or after January 1, 2010; however, absent congressional action prior to the end of 2010, the estate tax will be reinstated for decedents dying on or after January 1, 2011. Economic Growth and Tax Relief Reconciliation Act of 2001, Pub. L. No. 107-16, $\S \S 501,901(\mathrm{a})$, 115 Stat. $38,69,150$.

${ }^{201}$ See, e.g., I.R.C. $\$ 2032 \mathrm{~A}$ (special estate tax valuation rule for certain farming and business property passed to "qualified heirs"); id. $\S 6166$ (allowing stock owned by family members to be aggregated for purposes of determining whether to permit the extension of time to pay estate tax for estates comprised largely of closely held business interests).

${ }^{202}$ See 1 U.S.C. $\& 7$ (2006) (defining "spouse"). 
For instance, the income tax exclusion for gifts and bequests does not embrace all transfers for less than fair market value. ${ }^{203}$ The exclusion applies only to a narrower class of transfers; namely, those made out of " detached and disinterested generosity,' 'out of affection, respect, admiration, charity or like impulses." "204 A transfer will not qualify for the exclusion if it "proceeds primarily from 'the constraining force of any moral or legal duty,' or from 'the incentive of anticipated benefit' of an economic nature."205 And a payment for services rendered will not qualify as a gift even if the transferor derives no economic benefit from the payment (the classic example of such a payment being a tip given after services have already been rendered). ${ }^{206}$ The distinction drawn between transfers made out of detached and disinterested generosity, on the one hand, and those stemming from a moral or legal duty or from the anticipation of some economic benefit, on the other hand, has led to litigation over whether transfers of property between unmarried different-sex cohabitants or from a disabled individual to a caregiver were excludible gifts or taxable payments for services rendered. ${ }^{207}$ This distinction also casts a pall of uncertainty over the correct income tax characterization of transfers between other members of nontraditional families. ${ }^{208}$

The estate and gift taxes only intensify these difficult characterization issues by employing a different definition of "gift" than that employed for income tax purposes. ${ }^{209}$ For estate and gift tax purposes, a "gift" generally includes any

${ }^{203}$ Comm'r v. Duberstein, 363 U.S. 278, 285 (1960) ("This Court has indicated that a voluntarily executed transfer of his property by one to another, without any consideration or compensation therefor, though a common-law gift, is not necessarily a 'gift' within the meaning of the statute."); see Wolder v. Comm'r, 493 F.2d 608, 611-12 (2d Cir. 1974) (applying Duberstein in interpreting $\S 102$ as it applies to bequests); Braddock v. United States, 434 F.2d 631, 632 (9th Cir. 1970) (same).

${ }^{204}$ Duberstein, 363 U.S. at 285 (quoting Comm'r v. LoBue; 351 U.S. 243, 246 (1956), and Robertson v. United States, 343 U.S. 711,714 (1952)).

${ }_{205}$ Id. (quoting Bogardus v. Comm'r, 302 U.S. 34, 41 (1937)).

${ }^{206} \mathrm{Id}$.

${ }^{207}$ E.g., Estate of Cavett v. Comm'r, 79 T.C.M. (CCH) 1662 (2000) (unmarried different-sex cohabitants); Reynolds v. Comm'r, 77 T.C.M. (CCH) 1479 (1999) (unmarried different-sex cohabitants); Miller v. Comm'r, 53 T.C.M. (CCH) 962 (1987) (bequests from individual disabled by stroke to caregivers); see generally Melvyn B. Frumkes, Taxation of Same-Sex Marriage and Live-Ins, 22 J. AM. ACAD. MATRIMONIAL LAW. 117 (2009).

${ }^{208}$ See, e.g., Infanti, Sodomy Statute, supra note 1, at 783-85 (describing the uncertainty surrounding the correct income tax characterization for transfers between members of same-sex couples).

${ }^{209}$ See, e.g., United States v. Davis, 370 U.S. 65,69 n.6 (1962) ("In interpreting the particular income tax provisions here involved, we find ourselves unfettered by the language and considerations ingrained in the gift and estate tax statutes.").

Perhaps to assuage the feelings and aid the understanding of affected taxpayers, Congress might use different symbols to describe the taxable conduct 
transfer for less than an adequate and full consideration in money or money's worth. ${ }^{210}$ This definition gives rise to interpretational issues concerning whether a transfer was made in exchange for money or money's worth (e.g., property or the provision of services) or was made in exchange for "[a] consideration not reducible to a value in money or money's worth, as love and affection, promise of marriage, etc." ${ }^{211}$ Furthermore, the estate tax (particularly through its application to property held in a joint tenancy with right of survivorship by anyone other than a married couple) and the generation-skipping transfer tax present significant traps for unwary members of nontraditional families. ${ }^{212}$

\section{Elective Nonrecognition Treatment}

As mentioned above, where I part company with the Law Commission is in answering the third of its questions: "If relationships matter, can individuals be permitted to designate the relevant relationships themselves?"213 In the context of its reexamination of the automatic rollover rule, the Law Commission summarily concluded that it is not feasible to allow taxpayers to identify their economically interdependent relationships for themselves. I disagree with this conclusion. Demonstrating that it is possible to answer this question in the affirmative, I have sketched below the outlines of a tax regime that would both be neutral with regard to transfers of property within economically interdependent relationships and allow

in the several statutes, calling it a "gift" in the gift tax law, a "gaft" in the income tax law, and a "geft" in the estate tax law.

Comm'r v. Beck's Estate, 129 F.2d 243, 246 (2d Cir. 1942).

${ }^{210}$ See I.R.C. $\$ 2043$ (a) (2006) (setting forth the extent of the estate tax inclusion where property is transferred during life but drawn back into the decedent's gross estate at death, and the transfer during life was for less than an adequate and full consideration in money or money's worth); id. $\S 2053$ (c)(1)(A) (limiting the deduction for claims against a decedent's estate to those "contracted bona fide and for an adequate and full consideration in money or money's worth"); id. $\S 2512$ (b) (providing that, "[w]here property is transferred for less than an adequate and full consideration in money or money's worth, then the amount by which the value of the property exceeded the value of the consideration shall be deemed a gift").

211 Treas. Reg. $\S 25.2512-8$ (as amended in 1992); see I.R.C. $\S 2043$ (b)(1) ("[A] relinquishment or promised relinquishment of dower or curtesy, or of a statutory estate created in lieu of dower or curtesy, or of other marital rights in the decedent's property or estate, shall not be considered to any extent a consideration 'in money or money's worth."'); Merrill v. Fahs, 324 U.S. 308 (1945) (release of marital rights not consideration in money or money's worth for gift tax purposes); Comm'r v. Wemyss, 324 U.S. 303 (1945) (promise of marriage not consideration in money or money's worth for gift tax purposes); see also Infanti, Sodomy Statute, supra note 1, at 785-87 (discussing the difficult gift tax characterization issues faced by same-sex couples).

212 Cain, supra note 24, at 692-97.

${ }^{213}$ See supra note 155. 
taxpayers to identify their economically interdependent relationships for themselves.

To work toward the goal of making the proposed U.S. individual tax filing system neutral with regard to transfers of property within economically interdependent relationships, I.R.C. $\S 1041$ (which affords nonrecognition treatment to transfers of property between married different-sex spouses) should be repealed and the categories of transfers that constitute realization events should be revisited. Along the lines of the Canadian tax system, all outright transfers of property at other than fair market value (including gifts and bequests) should be deemed to be taxable events for income tax purposes-that is, these transfers should be deemed dispositions of the transferred property in exchange for consideration equal to the property's fair market value. ${ }^{214}$ Correlatively, the transferor of the property should be required to realize and recognize any gain or loss inherent in the transferred property, and the transferee should take the property with a fair market value basis.

To accommodate and identify transfers between economically interdependent individuals, it will be necessary to provide an exception from this default treatment. In Canada, such an exception is found in the automatic rollover rule. The automatic rollover rule singles out a certain type of relationship (i.e., the conjugal couple) and automatically affords transfers between the parties to that relationship nonrecognition treatment (unless they elect otherwise). The Canadian approach to accommodating transfers between economically interdependent individuals is, however, fundamentally inconsistent with the approach taken in this Article. The Canadian approach is actually more consistent with the current U.S. joint return system, which singles out a certain relationship (i.e., the traditional family) and privileges it above all others. For this reason, I have rejected adopting the Canadian automatic rollover rule as part of this proposal.

Instead, under this proposal, all transferors (and not just conjugal couples, as in Canada) would be allowed to elect nonrecognition treatment on an outright transfer of property at other than fair market value (whether made directly to an individual or indirectly through a trust). ${ }^{215}$ It is worth noting that this proposal

214 This would affect transfers of appreciated property at less than fair market value by requiring the gain built into the property to be recognized and would likewise affect transfers of depreciated property at more than fair market value by disallowing artificial losses (i.e., the portion of the loss attributable to consideration paid in excess of fair market value).

${ }^{215}$ A modified version of this election should be available for part-gift, part-sale transfers (i.e., for transfers for some consideration, but less than the fair market value of the property). The election should shield from taxation only the difference between the fair market value of the property and the amount paid by the transferee. Through basis adjustments, any untaxed gain should be preserved in the hands of the transferee. Transfers for greater than the fair market value of the property should be ineligible for the election. These transfers should be subject to the default rule (i.e., the transferor should be treated as if she received consideration equal to the fair market value of the property in exchange for 
takes a step beyond even the reform recommended by the Law Commission of Canada, which would permit only those who live together in an economically interdependent relationship to benefit from nonrecognition treatment. Under my proposal, there would be no requirement that the transferor and transferee of the property live together. There would be no artificial limit on the size or composition of the economically interdependent relationships recognized for tax purposes or on the number of transfers for which nonrecognition treatment could be elected. ${ }^{216}$ There would not even be a formal requirement that the transferor and transferee be in an economicallý interdependent relationship. To underscore this point, let me emphasize that taxpayers would not be required to prove the existence of an economically interdependent relationship in order to be eligible to make a nonrecognition election; rather, as described below, having made the election would be one of the ways of identifying a taxpayer's economically interdependent relationships. ${ }^{217}$

Indeed, a significant benefit of requiring taxpayers to elect into nonrecognition treatment is that the election itself serves as a means of identifying the economically interdependent relationships that the taxpayer has entered into. This is an improvement over the current practice (here and in Canada) of having the tax system make an a priori determination about which relationships are (or ought to be) marked by economic interdependence. Moreover, by having each individual elect into nonrecognition treatment and identify for herself the economically interdependent relationships that she has entered into, this proposal respects the autonomy and liberty of each individual to form the relationships that

the property, and the transferee should take a basis in the property equal to its fair market value). Any consideration in excess of the fair market value of the property should be subject to recharacterization in accordance with the surrounding facts and circumstances (e.g., as a gift, compensation for services rendered, etc.).

It is also worth noting that I have not distinguished here between domestic and crossborder transfers of property within economically interdependent relationships, notwithstanding Congress's evident concern with extending nonrecognition treatment to such transfers. See I.R.C. $\S 1041$ (d) (excluding transfers to nonresident alien spouses from the ambit of the nonrecognition rule of $\S 1041$ ). Even without the benefit of $\S 1041$, a U.S. citizen or resident alien can currently make a gift of property to a nonresident alien without paying tax on the appreciation in that property, despite the fact that the donee may not be subject to tax on a subsequent sale or disposition of the property. I.R.C. $\S 871$; Treas. Reg. $\S 1.1441-2(b)(2)(i)$ (as amended in 2008). Making the nonrecognition election available in this situation would, therefore, honor the economically interdependent relationships of the taxpayer without opening the door to abuse (or, at the very least, to behavior that we do not currently consider to be worthy of deterrence).

${ }^{216}$ This might sound overly generous; however, please do keep in mind that, under current U.S. tax rules, an individual is not limited in the number or size of gifts that can be made without the recognition of gain, see 2 BITTKER \& LOKKEN, supra note 197, ๆ 40.3, and neither is the recipient of a gift limited in the number or size of gifts that can be excluded from gross income, I.R.C. $\$ 102$.

${ }^{217}$ See infra Part IV.C. 
she wishes and rejects the notion that the tax system ought to provide incentives for entering into a certain type of relationship. ${ }^{218}$

For the sake of clarity and to better achieve the goal of identifying economically interdependent relationships, transfers made in the ordinary course of the transferor's trade or business, or received in the ordinary course of the transferee's trade or business, should be ineligible for the election; in other words, all transfers in the ordinary course of business should be presumed to be made in exchange for fair market value. ${ }^{219}$ Transfers of property outside of the context of a trade or business would be eligible for the nonrecognition election only if the transfer were made at other than fair market value. This requirement should ensure that nonbusiness, profit-oriented transactions (e.g., the sale of stock by an investor) would be ineligible for the nonrecognition election, and should leave only nonmarket, non-arm's-length transfers-those most likely to be made in the context of an economically interdependent relationship-eligible for the nonrecognition election.

Not every nonmarket, non-arm's-length transfer of property will be indicative of an economically interdependent relationship. By using the election into nonrecognition treatment as a marker of economic interdependence, this proposal actually provides taxpayers with an incentive to correctly identify their economically interdependent relationships. As described more fully below, ${ }^{220}$ making the nonrecognition election with respect to a transfer will trigger the application of attribution of ownership and other antiabuse rules that would turn on the existence of an economically interdependent relationship (rather than on the existence of certain conjugal or familial relationships, as they do now). In essence, taxpayers would be given a choice between two mixes of advantages and disadvantages: On the one hand, a taxpayer could elect the benefit of nonrecognition treatment, but at the price of triggering disadvantageous attribution of ownership and antiabuse rules. The application of these attribution and antiabuse rules would necessarily require both the taxpayer and the transferee of the property to share information regarding their business and investment holdings-information that many taxpayers will be loathe to share with anyone other than someone with whom they share a close, economically interdependent relationship. On the other hand, a taxpayer could opt for the default treatment of a deemed disposition at fair market value and pay tax on the transfer of appreciated property, but rest assured that this transfer alone would not trigger the attribution of ownership and antiabuse rules, thereby obviating the need for reciprocal

${ }^{218}$ Contra The President's Radio Address, 42 WeEkLy COMP. Pres. Doc. 719 (Apr. 24, 2006) ("[O]ur Tax Code should encourage marriage, not penalize it.").

${ }^{219}$ See Treas. Reg. $\S 25.2512-8$ (as amended in 1992) (providing that, for gift tax purposes, "a sale, exchange, or other transfer of property made in the ordinary course of business (a transaction which is bona fide, at arm's length, and free from any donative intent), will be considered as made for an adequate and full consideration in money or money's worth").

${ }^{220}$ See infra Part IV.C. 
disclosure of information regarding business and investment holdings between the taxpayer and the transferee of the property. ${ }^{221}$

When a transferor makes a nonrecognition election upon the transfer of property, the transferee of the property should correlatively take a transferred basis in the property (thereby preserving any gain or loss inherent in the property at the time of the transfer for later recognition). Because full ownership of the property will have shifted, the transferee should be taxed on any income generated by the property and any gain recognized on a subsequent disposition of the property and should be allowed a deduction for any loss incurred with respect to the property. ${ }^{222}$ As Marjorie Kornhauser has explained, studies indicate that, even when financial resources are pooled, the identity of the holder of legal title to property influences the measure of control that each person has over the ostensibly pooled resources. ${ }^{223}$ This control is important because, as Kornhauser further noted, one of the basic principles of our tax system is "that the person who controls the income should be taxed on it even if another benefits." ${ }^{, 24}$ Moreover, Lisa Philipps has made a strong feminist case for repealing the Canadian attribution rules as applied to outright transfers of property, arguing that repeal of these rules "would encourage more equal sharing of economic resources between men and women . . . would respect women's agency as property owners and . . . would recognize women's unpaid

${ }^{221}$ A taxpayer would be indifferent between recognition and nonrecognition if the transferred property had a fair market value equal to its basis. In this relatively rare situation, these rules would fall short of their goal of identifying economically interdependent relationships. In addition, in the case of depreciated property, these rules would, at first glance, seem to provide an incentive to opt for the default treatment in order to obtain a deduction for the loss. However, Part IV.C., infra, addresses the possibility of taking into account both break-even transfers and transfers of loss property in ascertaining whether an economically interdependent relationship exists between individuals.

${ }^{222}$ See, e.g., Comm'r v. Sunnen, 333 U.S. 591, 608-10 (1948) (an individual's assignment of a patent license contract "left him with something more than a memory"; indeed, the individual's continuing ability to control the income from the contracts through his continued ownership of the underlying patents as well as his stock ownership in the corporation to which he had nonexclusively licensed the patents justified his having to include that income in his gross income for federal tax purposes); Corliss v. Bowers, 281 U.S. 376 (1930) (holding that an individual may continue to be taxed on income from transferred property where the individual has retained the power to revoke the transfer); see also Crago, supra note 74 , at 37-38 (recommending that there be further study to determine whether repealing the Canadian attribution rules for outright transfers would result in a more equal sharing of wealth within families); Lahey, Tax Unit, supra note 78, at 300 (contemplating the repeal of the Canadian attribution rules on property transfers if the rollover rules could be designed to encourage men to transfer property to women and children). Contra London, Marital Tax Unit, supra note 78, at 310-11 (opposing repeal of the Canadian attribution rules as applied to spouses on the ground that it would be "more regressive than is tolerable" because it would primarily benefit the wealthy).

${ }^{223}$ Komhauser, supra note 36, at 88-91; Kornhauser, supra note 193, at 1427-31.

${ }^{224}$ Kornhauser, supra note 36, at 109. 
contributions to household welfare." 225 Admittedly, the person who holds title is not the only factor that influences control over property; ${ }^{226}$ nevertheless, the shifting of legal title (at least in the context of the outright, no-strings-attached transfers that are the subject of this proposal) does have the advantage of being both a meaningful ${ }^{227}$ and an easily administrable marker of when an individual has relinquished control of property that can be applied to diverse economically interdependent relationships. ${ }^{228}$

Any nonrecognition election should, therefore, be limited to outright transfers of all or a portion of the property. If a transferor reserves any significant power over or any interest in ostensibly transferred property, the transfer of the affected portion of the property should no more be considered "complete" for income tax purposes than it would generally be for gift tax purposes. ${ }^{229}$. In the case of such an incomplete transfer, the transferor would not be required to reckon up her gain or loss because she would continue to be considered the owner of the affected portion of the property for income tax purposes. Likewise, notwithstanding the transfer, the transferor should continue to be subject to tax on income received with respect to the affected portion of the property as well as on any gain (and, conversely, should be permitted to deduct any loss) on the disposition of the affected portion of the property.

By limiting the nonrecognition election to outright transfers, the income tax would not be an impediment to the shifting of property ownership among

${ }^{225}$ Philipps, supra note 134, at 9; see also id. at 9-23 (making this case in detail).

${ }^{226}$ See Kornhauser, supra note 193, at 1442-43. The alternative methods that Kornhauser proposes for allocating income from property are too narrowly tailored to conjugal couples to be of use in formulating a proposal that is aimed at a far broader and more diverse group of relationships.

${ }^{227}$ Some might contend that the shifting of legal title is not always a meaningful event, as when a taxpayer transfers legal title to a trustee who will hold the property in trust for the benefit of the taxpayer. Nevertheless, by confining eligible transfers to outright, nostrings-attached transfers, as described in the next paragraph of the text above, the mere transfer of legal title to a trustee who will hold property for the benefit of the taxpayer will not be eligible for the nonrecognition election-nor will transfers to a trustee where the taxpayer has retained significant power over the property.

${ }^{228}$ To deter purely tax-motivated income-splitting through the transfer of incomeproducing property, it may be advisable to adopt a rule along the lines of I.R.C. $\S 1031(f)$ (2006). Thus, if a transferee of property with respect to which a nonrecognition election was made disposes of that property in a taxable transaction within a specified period after receiving the property, then any income from the property during the period that the transferee held it-as well as any gain or loss recognized on the taxable disposition of the property-should be attributed to the transferor for income tax purposes.

${ }^{229}$ See Treas. Reg. $\$ 25.2511$-2(b) (as amended in 1999) (a gift is complete when "the. donor has so parted with dominion and control as to leave in him no power to change its disposition, whether for his own benefit or for the benefit of another"). But see id. $\S$ 25.2511-2(d) ("A gift is not considered incomplete, however, merely because the donor reserves the power to change the manner or time of enjoyment."). 
economically interdependent persons. In fact, it might even serve to encourage a more equal sharing of property by persons in economically interdependent relationships. ${ }^{230}$ Yet, there would be no encouragement for individuals who own property to use those with whom they have economically interdependent relationships as little more than a tax shelter (i.e., by transferring property to them only for tax purposes). The current joint filing regime provides just such an incentive, as do the estate and gift tax qualified terminable interest property (QTIP) rules. ${ }^{231}$ By avoiding this pitfall, the nonrecognition election would achieve an appropriate balance between the individual and her connections with others by accommodating the transfer of property within economically interdependent relationships but discouraging the exploitation of one party to that relationship by another.

\section{Transfers of Property in Exchange for Services Rendered}

It is usually a simple task to ascertain whether property is being transferred in exchange for other property (or no property at all). It can, however, be more difficult to determine whether a transfer is being made gratuitously versus in exchange for services rendered. The difficult dividing line here is between services for which payment is expected and being made (i.e., where service provider and service recipient are acting at arm's length) and services for which no explicit payment is expected or made (i.e., where service provider and service recipient are not acting at arm's length). ${ }^{232}$ Property transfers in the former category should be

${ }^{230}$ See supra note 50 and accompanying text.

${ }^{231}$ For a reference to Amy Christian's discussion of this incentive effect of the joint return, see supra note 44 and accompanying text. The QTIP trust allows married taxpayers (usually, husbands) to obtain the benefit of the estate and gift tax marital deductions without actually transferring ownership and control of property to their spouses (usually, wives). See generally Gerzog, supra note 112. As mentioned earlier, the same criticisms have been leveled at Canadian spousal trusts. See supra note 112.

Incidentally, a nonrecognition election limited to outright transfers presents the possibility for a certain measure of simplification in our tax system by harmonizing the income and gift tax rules for determining whether a transfer is complete and further holds out the possibility of repealing the complex grantor trust rules found in I.R.C. $\S \S 671-677$. See Robert T. Danforth, A Proposal for Integrating the Income and Transfer Taxation of Trusts, 18 VA. TAX REV. 545, 549-50, 602, 604, 619 (1999) (arguing in favor of the integration of the income tax grantor trust rules and the gift tax rules concerning when a gift is considered complete, in part because of the resulting simplification benefits associated with such a move); Jay A. Soled, Reforming the Grantor Trust Rules, 76 NOTRE DAME L. REV. 375, 413-14, 417-18 (2001) (same).

${ }^{232}$ Though the paradigmatic example of services provided in a non-arm's-length context is that of the traditional family with a wife who performs most (if not all) household services for her husband and children, services might also be provided in a nonarm's-length context when two siblings live together, when a child cares for a parent, or when someone cares for an elderly friend or neighbor. Such services can also take the form 
ineligible for the nonrecognition election as regular market-based transactions, but transfers in the latter category should be eligible for the nonrecognition election because they bespeak an economically interdependent relationship. ${ }^{233}$

Presently, for income tax purposes, the line between these two categories of transactions is drawn wholly by reference to the intent of the transferor. As the U.S. Supreme Court stated in Commissioner v. Duberstein, "the most critical consideration ... is the transferor's 'intention.' 'What controls is the intention with which payment, however voluntary, has been made." ${ }^{234}$ In the context of this proposal, a better approach would be to abandon Duberstein and to buttress the disqualification of transfers made or received in the ordinary course of business with a further disqualification for property received by the transferee from a transferor in connection with services rendered in a transaction entered into for profit (though not connected with a trade or business of the transferee). ${ }^{235}$ These

of unpaid market labor; for example, when a spouse, partner, or child works in the family business or assists a family member in performing employment duties without receiving remuneration. Lisa Philipps, Helping out in the Family Firm: The Legal Treatment of Unpaid Market Labor, 23 WIS. J.L. GENDER \& SOC'Y 65, 66-98 (2008).

${ }^{233}$ As Lisa Philipps has explained, the line between market and nonmarket transactions in this context is blurry at best. See id. at 99-102 (explaining how unpaid market labor highlights the problems associated with the market/family dichotomy). In keeping with the general approach of this proposal to ensure that the tax laws interfere as little as possible with the formation of economically interdependent relationships, I have erred on the side of affording individuals wide latitude in determining for themselves whether they fall on the market or nonmarket side of this dividing line. This respects the autonomy of the service provider and service recipient while encouraging the redistribution of wealth from the service recipient to the service provider. For a discussion of other steps that might be taken that would help to better recognize the value of unpaid caregiving, see Philipps, supra note 134, at 21-23.

${ }^{234}$ Comm'r v. Duberstein, 363 U.S. 278, 285-86 (1960) (quoting Bogardus v. Comm'r, 302 U.S. 34, 43 (1937), and then quoting id. at 45 (Brandeis, J., dissenting)).

${ }^{235}$ The fact that a transaction entered into for profit might turn out to be a losing venture would not by itself remove the transaction from this disqualification. The same phrase in I.R.C. $\S 165(c)(2)$ has been interpreted to similar effect. See 1 BITTKER \& LOKKEN, supra note 15, I 25.3 ("Since a disposition of depreciated property cannot produce a profit, the 'transaction' to which $\S 165(\mathrm{c})(2)$ refers is not the sale. Rather, the requirement is that the investment or activity must have been undertaken with the expectation of profit.").

This disqualification would not apply to transfers at other than fair market value to a transferee who has not rendered services to the taxpayer. By limiting the disqualification in this way, gratuitous transfers of investment property would not be inadvertently deemed ineligible for the nonrecognition election. Otherwise, only investment property purchased with a gratuitous transfer in mind might be deemed eligible for the nonrecognition election. Conversely, investment property (e.g., stock) purchased in a transaction entered into for profit and held by the taxpayer for some time with this profit motive might be held ineligible for the nonrecognition election upon a later change of holding purpose and subsequent gratuitous transfer of the property to another. Restricting the disqualification to 
disqualifications would clearly exclude routine business-related transfers (e.g., the payment of a bonus to an employee in property instead of cash) as well as other remunerative transfers (e.g., a transfer of property to an individual who performs paid household services for others on only a sporadic basis) from eligibility for the nonrecognition election.

These disqualifications would not, however, go so far as to exclude transfers of property between economically interdependent persons who also happen to provide household services or unpaid market labor to each other from eligibility for the nonrecognition election. These transfers would be eligible for the nonrecognition election because the services would not have been provided in the ordinary course of business or in a transaction entered into for profit. In contrast, under current law, a transfer of property to someone who provides household services or unpaid market labor to the transferor might very well be viewed as taxable compensation, because the transfer is not being made out of detached and disinterested generosity. Indeed, this ambiguity is the source of much of the difficulty in applying the income tax exclusion for gifts and bequests to nontraditional family arrangements. ${ }^{236}$

The buttressed disqualification rule also better squares with the current practical approach to difficult cases that fall in the borderline area between tax-free bequests and taxable payments for services rendered during the decedent's life:

The distinction between a tax-free bequest and a testamentary payment of belated or supplemental compensation is difficult to administer, especially in the case of domestic servants and trusted advisers whose personal relationships with the decedent often ripen into intimate friendships and who sometimes become virtual members of the family. If the decedent did not agree to leave anything by will to the beneficiary, a legacy ordinarily qualifies as a tax-free bequest .... The more vague and informal the understanding, the more it resembles a garden variety bequest by a lonely testator, who rewards a relative providing solace in the form of personal attention in preference to other relatives who contented themselves with verbal professions of affection. ${ }^{237}$

the context where services are rendered avoids this problem. As described above, see supra text following note 219 , true profit-oriented transfers should be excluded from eligibility for the nonrecognition election by the restriction of the election to transfers at other than fair market value.

${ }^{236}$ See supra notes 207 and 208 and accompanying text. In the case of the traditional family, one spouse's transfer of property to the other as compensation for the provision of household services or unpaid market labor is not a taxable event by reason of I.R.C. $\S 1041$, which affords the transferor nonrecognition treatment on the transfer of property to a spouse or former spouse and deems the transferee to have acquired that property as a (nontaxable) gift. Section 1041 therefore elides this significant interpretational difficulty in the context of traditional families.

${ }^{237} 1$ BITTKER \& LOKKEN, supra note 15, 10.3.1. 
By focusing on the intention of the service provider rather than on the intention of the service recipient, it may prove easier to distinguish property transfers between individuals in economically interdependent relationships from payments for services rendered. After all, a service provider who enters into a transaction to make a profit is unlikely to rely on a "vague and informal ... understanding" about the possibility of payment, and is more likely to require that any arrangement be memorialized in writing or, at the very least, be the subject of an oral understanding before starting work. Less formal arrangements are indicative of a lack of profit motive for providing the services and suggest the existence of an economically interdependent relationship that justifies eligibility for the nonrecognition election.

\section{De Minimis Exception}

As this proposal contemplates that taxpayers will elect nonrecognition treatment, some reporting and sharing of information will be required of taxpayers. ${ }^{238}$ To ease this burden, it would be advisable to adopt a de minimis rule along the lines of the one that exists in the Canadian tax system. Recall that, in Canada, for all dispositions of personal-use property, the taxpayer's adjusted cost base is deemed to be equal to the greater of $\$ 1,000$ or the taxpayer's actual adjusted cost base, and the taxpayer's proceeds of disposition are deemed to be equal to the greater of $\$ 1,000$ or the actual proceeds of disposition. ${ }^{239} \mathrm{~A}$ reasonable figure for de minimis transfers of personal-use property (subject, of course, to adjustment for inflation) should be adopted here as well. It may also be advisable to adopt an antiabuse rule (again, along the lines of the one that exists in the Canadian tax system) that prevents taxpayers from splitting up what is really one transfer into smaller component parts to take undue advantage of this de minimis exception by multiplying it severalfold. ${ }^{240}$

${ }^{238}$ Cf. Temp. Treas. Reg. $\S 1.215-1 \mathrm{~T}$ (1984) (requiring the payee of alimony to furnish her Social Security number to the payor of alimony, so that he can enter it on his income tax return when taking a deduction for the alimony payment); Temp. Treas. Reg. $\S 1.1041-1 \mathrm{~T}, \mathrm{Q} \& A-14$ (as amended in 2003) (requiring a transferor of property subject to $\S 1041$ to, "at the time of the transfer, supply the transferee with records sufficient to determine the adjusted basis and holding period of the property as of the date of the transfer," because the transferee of the property takes the transferor's basis for purposes of later computing a gain or loss on the sale or other disposition of the property, I.R.C. $\S$ $1041(\mathrm{~b})(2))$.

${ }^{239}$ See supra note 101 and accompanying text.

${ }^{240}$ See supra note 101. 


\section{Transfer Tax Coordination}

As a coordinating measure, the estate and gift tax marital deductions should be repealed. ${ }^{241}$ Because the nonrecognition election would benefit only those with property and not those whose income consists solely of wages, it would be advisable to retain the estate and gift taxes to enhance the overall progressivity of the tax system. The estate and gift taxes could also be used (as they have been in the past) as a means of deterring transfers of property solely to gain an income tax advantage. And, nicely dovetailing with the approach to individual income tax filing outlined here, Bridget Crawford has already proposed a reform of the estate and gift taxes that would render these transfer taxes similarly relationship neutral and reserve their application for only the wealthiest among us. ${ }^{242}$

\section{Attribution of Ownership and Other Antiabuse Rules}

Another means of deterring purely tax-motivated transfers of property is to attach tax disadvantages to economically interdependent relationships as well as the advantage of the nonrecognition election. Put differently, many of the attribution of ownership rules and related party antiabuse rules that currently exist in the U.S. federal income tax could be amended to apply to "economically interdependent persons" rather than to persons (e.g., spouses and family members) who are now merely assumed (correctly or incorrectly) to be in economically interdependent relationships. ${ }^{243}$ For example, I.R.C. $\$ 267$ could be amended to disallow any loss realized and recognized on a transfer between economically interdependent persons (or between persons who soon thereafter enter into an economically interdependent relationship), just as losses are currently disallowed between spouses and common-law partners in Canada. ${ }^{244}$ In addition, the imputed interest rules of I.R.C. $\S 7872$ could be amended to apply to any below-market loans between economically interdependent persons. By placing all such loans on an equal footing with loans made at arm's length, there should be no need to attribute any income produced by the loan proceeds to the lender, as occurs for

${ }^{241}$ I.R.C. $\S \S 2056,2523$.

${ }^{242}$ See generally Bridget J. Crawford, One Flesh, Two Taxpayers: A New Approach to Marriage and Wealth Transfer Taxation, 6 FLA. TAX REV. 757 (2004).

${ }^{243}$ See supra notes 187-90 and accompanying text for a discussion of how notions of economic interdependence undergird many attribution and antiabuse rules. To hark back to the Law Commission's methodology, see supra note 155 and accompanying text, these attribution and antiabuse rules serve legitimate objectives, and it is appropriate to take relationships into account for purposes of these rules because those relationships are the source of possible abuse. This proposal improves upon the existing rules by better targeting the types of relationships that are the source of abuse and allowing the taxpayer a role in identifying the relationships that are most likely to be the source of abuse.

${ }^{244}$ See supra notes 147-49 and accompanying text. 
Canadian tax purposes. ${ }^{245}$ Furthermore, the attribution of ownership rules of I.R.C. $\S \S 267$ and 318 , which are incorporated by reference in many other U.S. federal income tax provisions, could be amended to apply to economically interdependent persons instead of "family members."

For this purpose, the term "économically interdependent persons" should be specifically defined to include the transferor and transferee of property with respect to which a nonrecognition election has been made. ${ }^{246}$ This is where the elective aspect of nonrecognition treatment plays an important signaling role. When an individual makes a transfer of property at other than fair market value and elects not to recognize gain - with full knowledge that this election will entail not only an immediate tax advantage, but also ongoing tax and nontax disadvantages - the individual taxpayer will have signaled the existence of an economically interdependent relationship with the transferee. If the transferor declines to make the nonrecognition election, then she will recognize any gain or loss on the deemed disposition of the property for an amount equal to the property's fair market value. Because, from a tax perspective, the transferor and transferee are dealing at arm's length, the two need not be considered to be parties to an economically interdependent relationship by reason of this transfer alone. ${ }^{247}$

Because gratuitous transfers of cash would be free from income tax even without a nonrecognition election, the term "economically interdependent persons" should be defined to include the transferor and transferee of a specified level of cash beyond a threshold amount designed to cover routine gifts and other gratuitous transfers that would be made even in the absence of an economically interdependent relationship (i.e., a level akin to the current gift tax annual exclusion) ${ }^{248}$ In determining whether a given cash transfer should be included in computing this threshold, rules similar to those outlined above for determining whether a transfer of property in exchange for services rendered should be eligible for the nonrecognition election should be applied. ${ }^{249}$ Cash transfers should also be

${ }^{245}$ See supra text accompanying notes $120-23$.

${ }^{246}$ In the case of transfers in trust, all ascertainable beneficiaries of the transfer should be included among the group of economically interdependent persons.

${ }^{247}$ For those worried about the possibility of abuse of the nonrecognition election by those who wish to avoid the application of antiabuse rules, continue reading on in the text above.

${ }^{248}$ I.R.C. $§ 2503$ (b) (2006). The threshold could be applied separately each year, or it could be applied to a multiyear average of cash transfers from the taxpayer to a given transferee, or these two (or possibly other) approaches could be combined in an effort to forestall manipulation.

${ }^{249}$ See supra Part IV.B.3. Correlatively, the includibility of a cash transfer in the gross income of the transferee should likewise be determined under these rules. In keeping with the general steps taken in this proposal toward the harmonization of the income tax and gift tax treatment of gifts, it will be necessary to further refine the income tax treatment of transferees to clear up any remaining confusion created by the Duberstein standard in situations other than a potential transfer of cash in exchange for services. See supra Part 
covered whether they are made outright or through a below-market loan, whether they are made in a lump sum or in a series of payments over a specified period of time, and should be aggregated together if they are part of a plan to avoid these rules.

To prevent abuse of the de minimis exemption of personal-use property, a specified aggregate amount of transfers of such property might trigger their treatment as deemed transfers of cash (equal to the aggregate fair market value of the property falling under this exemption) for purposes of applying this threshold. Additionally, if there is concern that taxpayers might refuse to make the nonrecognition election purely to avoid the disadvantages of being classified as economically interdependent persons (e.g., in the case of a transfer of property with a fair market value equal to its basis or of property that has appreciated very little) or to reap the benefit of deducting a loss on the deemed disposition of property, it might be advisable to break certain deemed dispositions of property into their component parts. Under the proposal above for taxing transfers of property between economically interdependent persons, a transfer of property at other than fair market value automatically triggers a deemed disposition of the property in exchange for an amount equal to the property's fair market value (unless a nonrecognition election is made). Similar to the way in which I.R.C. $\S$ 7872 currently deals with the tax consequences of below-market loans, the transferor of property with either (1) a built-in loss or (2) no (or possibly even a de minimis amount of built-in gain could be deemed first to transfer an amount of cash equal to the fair market value of the property to the transferee as a gift. The transferee would then be deemed to transfer that same amount back to the transferor as consideration for the transfer of the property. The deemed transfer of cash as a gift could then be required to be aggregated with the other cash transfers made by the transferor to the transferee during the year for purposes of applying the threshold for classification as "economically interdependent persons" described in the previous paragraph.

The term "economically interdependent persons" should be further defined to include persons bound by a support obligation. It should not matter whether that support obligation is imposed by statute (e.g., the obligation of married spouses, domestic partners, or parties to a civil union to support each other and of parents to support their children), undertaken by contract (e.g., an obligation undertaken by the parties to a private domestic partnership agreement), or represented to exist to third parties (e.g., when two individuals represent that they will support each other to a local governmental entity when registering as domestic partners or to an employer when applying for domestic partner benefits). However, the existence of a support obligation, by itself, should not conclusively determine the existence of

IV.B.1. This further refinement is, however, beyond the scope of this Article and must be left for another day. When fashioning any such refinements, it will also be necessary to consider the Law Commission of Canada's four-part methodology to ensure that the changes are relationship neutral. See infra Part IV.F. 
an economically interdependent relationship. There are, for example, spouses who are bound by a support obligation but who keep their finances separately. Thus, an economically interdependent relationship should be considered to exist only when an individual bound by a support obligation actually provides at least a specified fraction (e.g., one-quarter or one-third) of the support of the other. ${ }^{250}$ By requiring one person to provide a specified percentage of the support of the other, this rule will ensure that those who are currently assumed to be economically interdependent (e.g., spouses) are only so treated if they actually share more than a de minimis amount of financial resources. This classification also comports with the studies that have shown that the earner of income tends to control how that income is spent. ${ }^{251}$

This definition of "economically interdependent persons" should be written in the disjunctive; that is, falling into any one of these categories should indicate the existence of an economically interdependent relationship between the affected individuals. Moreover, these economically interdependent relationships should be deemed to continue for a specified period of time; for example, the relationship could be deemed to continue for five or ten years ${ }^{252}$ following the last nonrecognition election, transfer of cash above the threshold amount, repayment of a below-market loan, or provision of support above the requisite level. By adopting a bright-line rule, there might be a possibility for individuals to engage in tax planning; however, a sufficiently lengthy period of time (such as the five or ten years mentioned above) would militate against such planning because of the significant likelihood of intervening nontax events that might defeat any taxplanning objective. ${ }^{253}$ Conversely, the occurrence of an event. with nontax

${ }^{250}$ Naturally, this raises a factual question, but it is no different from the factual question raised by existing requirements concerning the level of support that one individual must provide to another in order to claim that person as a dependent for tax purposes. I.R.C. $\$ 152(\mathrm{c})(1)(\mathrm{D}),(\mathrm{d})(1)(\mathrm{C})$.

${ }^{251}$ See supra note 224 and accompanying text.

${ }^{252}$ Or some other period of time that is long enough to deter those acting at arm's length from attempting to act in concert to abuse these tax rules.

${ }^{253}$ See, e.g., I.R.C. $\S 302$ (c)(2) (allowing a waiver of family attribution for purposes of $\S 302$ where the redeemed shareholder agrees not to acquire a prohibited interest in the redeeming corporation for ten years).

A redemption of all of a shareholder's stock is properly treated as a sale because it terminates the shareholder's interest in the corporation as effectively as a sale to a third person. The sale analogy is not appropriate, however, if, after the redemption, members of the ex-shareholder's immediate family own stock. It is sufficiently possible that the seller will thereby continue his interest in the corporation (without interference from the outside that might have resulted from a sale to a third person) so that an attribution of his relative's shares to him is a reasonable rule of thumb. If the seller is willing, however, to forgo for a ten-year period any interest in the corporation (other than an interest retained as a 
consequences that clearly ruptures the relationship (e.g., divorce or death) could be deemed to result in the earlier termination of the economically interdependent relationship because the likelihood of manipulation of the tax rules would be low.

\section{Attribution of Income}

As described above, this proposal eschews the wholesale adoption of the Canadian attribution of income rules. A more limited attribution rule would apply under this proposal and require the attribution of income only when a transferor retains some power over or interest in the transferred property, because, in that situation, the transferor would still continue to be treated as the owner of the property for tax purposes. The U.S. case law that has developed concerning the assignment of income, which parallels the Canadian statutory assignment of income rules described above, ${ }^{254}$ should continue to be applied after a move to individual filing to guard against unwarranted income splitting.

Given the relationship between the creation of the income-splitting joint return and the community property-common law divide in the United States, ${ }^{255}$ a few words are also in order regarding this proposal's treatment of individuals who are subject to state community-property regimes. In order to further relationship neutrality and to end the privileging of marriage in our tax laws, state communityproperty laws should be disregarded when applying federal income tax rules. ${ }^{256}$ In making the case against recognizing community-property interests for federal income tax purposes, one commentator has observed:

[S]ome critics contend that community property law is far from being the great protector of married women's rights. While these laws create rights for the wife (as well as for the husband) during marriage, community property laws usually come into play only upon death or divorce. During marriage, there is no guarantee that the dual ownership afforded under community property law reflects any actual sharing of control over marital assets. In California, for example, one spouse has the right to sell or to encumber certain types of the couple's personal property (such as stocks and bonds) without the consent of the other

creditor or acquired involuntarily by bequest), it is reasonable to waive the family attribution rules and treat the redemption as a sale.

BITTKER \& EUSTICE, supra note 189, - 9.04[2][a].

${ }^{254}$ See supra text accompanying notes $116-19$.

${ }^{255}$ See supra text accompanying notes 30-32.

256 State community-property laws are already disregarded in the application of a number of federal tax provisions. See, e.g., I.R.C. $\S \S 32(\mathrm{c})(2)(\mathrm{B})(\mathrm{i}), 219(\mathrm{f})(2)$, $220(\mathrm{~b})(4)(\mathrm{C}), 448(\mathrm{~d})(4)(\mathrm{A}), 457(\mathrm{e})(7), 530(\mathrm{f}), 879$. 
spouse. In this way, a husband can deprive his wife of considerable control over these types of community assets. ${ }^{257}$

In view of these critiques, taxation should track ownership. If couples in community-property states wish to split income produced by property, then they should be required to transfer legal title to that property between them-with all of the attendant consequences in terms of shifting the balance of power with regard to the control of the property-just as everyone else must. Ignoring communityproperty laws, then, the income earned by each person should be taxed to that person, as required by Lucas v. Earl, ${ }^{258}$ and the income from property should be taxed to the person who holds legal title to that property.

\section{E. Allocation of Expenses}

In terms of the allocation of expenses, in keeping with the system's basic focus on the individual, the person who incurs an expense should be the one entitled to the deduction for that expense. If another pays an expense on the taxpayer's behalf, then the transaction should be broken into its constituent parts and taxed in accordance with the appropriate characterization of each leg of the transaction. ${ }^{259}$ In other words, the payment of the expense should be considered income to the taxpayer. Whether or not that income should be included in the taxpayer's gross income would depend upon its character. Thus, if the payment of the expense were in the nature of a gift, then the resulting income would be excluded from gross income by I.R.C. \& 102; however, if it were in the nature of a payment for services rendered, then the resulting income would be included in gross income under I.R.C. $\S 61(\mathrm{a})(1)$. The taxpayer would then be entitled to deduct the expense- that is, if the expense were of a type that would otherwise be deductible if paid by the taxpayer herself.

If a taxpayer is unable to use a deduction because she has insufficient income, then the taxpayer should not be permitted to transfer the unused portion of the

${ }^{257}$ Davis, supra note 36, at 239 (footnotes omitted).

Even when property is clearly community property under the law, each spouse does not always have equal access to the property. Sometimes this is the fault of the law itself since it does not always provide for equal participation by each spouse in the management and control of the property. Although older community property laws, which gave sole management to the husband, generally have been revised, complete joint management for all community property assets does not exist, even in theory. Even when the law does provide for joint management, reality often does otherwise.

Kornhauser, supra note 193, at 1416 (footnote omitted).

${ }^{258} 281$ U.S. 111 (1930).

${ }^{259}$ Old Colony Trust Co. v. Comm'r, 279 U.S. 716, 729-30 (1929). 
deduction to another taxpayer, as is sometimes possible in the Canadian tax system. ${ }^{260}$ Allowing one taxpayer to make a naked transfer of unused tax benefits to another has no tax policy justification in a tax system based on the individual. Moreover, accommodating the economically interdependent relationships that taxpayers enter into is fundamentally different from affirmatively rewarding those who enter into such relationships with tax benefits. ${ }^{261}$

If Congress wishes a taxpayer who does not have sufficient income to benefit from a deduction to nonetheless receive that benefit, then the appropriate mechanism for providing the benefit is either to convert the deduction into a refundable tax credit or to shift the delivery of the benefit out of the tax system entirely. ${ }^{262}$ These alternatives also have the advantage of ensuring that the benefit gets to the intended recipient rather than giving it to a third person whom the government must merely hope and trust will deliver that benefit to the intended recipient.

For administrative reasons, however, it may be advisable to allow taxpayers who use a joint account to pay for certain expenses that are difficult to trace (e.g., charitable donations) to allocate the deduction (or credit) for that expense between themselves as they see fit. ${ }^{263}$

\section{F. Other Code Provisions that Take Relationships into Account}

The preceding sections of this Part merely provide the broad outlines of an individual filing regime that decentralizes family. Of course, there are many other provisions in the Internal Revenue Code that turn on the existence of a familial or marital relationship between the taxpayer and others. It is beyond the scope of this

${ }^{260}$ See Brooks, supra note 78, at 73-74 (arguing against the ability of spouses to transfer unused credits to each other on the ground that it has the "peculiar effect" of allowing someone who owes no tax to get the benefit of the credit if married but not if that same person is unmarried); Crago, supra note 74, at 34-36 (arguing that the ability to transfer unused credits disproportionately benefits wealthy taxpayers).

${ }^{261}$ Putting this in terms of the Law Commission's methodology, see supra note 155 and accompanying text, neither rules that permit one taxpayer to deduct the expenses of another nor the naked transfer of tax benefits from one taxpayer to another serve a legitimate objective in a tax system that is based on the individual.

${ }^{262}$ See Brooks, supra note 78, at 73, 76-77 (in the Canadian context, advocating the conversion of nonrefundable tax credits into refundable tax credits and further advocating delivering support for child care expenses directly rather than indirectly through the tax system); see generally Lily L. Batchelder et al., Efficiency and Tax Incentives: The Case for Refundable Tax Credits, 59 STAN. L. REV. 23 (2006) (making the case on efficiency grounds for using refundable tax credits as the default structure for tax incentives designed to encourage socially beneficial behavior).

${ }^{263}$ See Brooks, supra note 78, at 77 (approvingly describing this as the current practice of the Canadian revenue authorities with respect to medical expenses and charitable donations). 
Article to analyze each and every one of these provisions to determine how they might (or might not) fit within an individual filing system.

If an individual filing system along the lines described in this Article were to be adopted, then it would be advisable to undertake an analysis of each of these provisions using the methodology developed by the Law Commission of Canada to determine whether relationship status is truly relevant to the objective to be achieved by the provision. In some cases, the Law Commission's questions will lead to a conclusion that a provision should be repealed (as was the case with the Law Commission's analysis of the Canadian tax credit for support of a spouse or common-law partner). In other cases, a provision will have a legitimate objective and it will be necessary to determine whether the provision should be amended to allow taxpayers to choose the relationships that are important to them (e.g., by replacing the existing listed relationships with a reference to "economically interdependent persons") or, if this proves impracticable, whether the provision should be amended in some other way to better tailor it to the relevant relationships.

By way of example, it seems that the alimony inclusion-deduction regime of I.R.C. $\S \S 71$ and 215 , which allows different-sex couples to benefit from the income-splitting privilege even after the breakup of their relationship, would be ripe for reconsideration and probably repeal after the adoption of this proposalafter all, the foundation for this proposal is the abolition of the income-splitting joint return. ${ }^{264}$ Similarly, it would seem that the medical expense deduction of I.R.C. § 213-which allows a deduction for expenses paid for medical care rendered to the taxpayer, the taxpayer's spouse, and the taxpayer's dependentswould likewise be ripe for reconsideration and amendment or elimination. After review, it might be concluded that $\S 213$ should be repealed because the issue of government support for extraordinary medical expenses is better addressed outside of the tax system in the context of the broader, ongoing debate over health care reform. Alternatively, it might be concluded that the deduction in $\S 213$ should be redesigned as a refundable tax credit for extraordinary medical expenses- to be claimed by the taxpayer who received the medical care and actually incurred the extraordinary medical expenses. ${ }^{265}$ Other examples abound; however, these provisions are an obvious starting point for reconsidering the role of relationships in the U.S. federal income tax laws.

\section{CONCLUSION}

This Article began with a summary of the critiques of the current U.S. joint filing regime. All of these critiques call the legitimacy of the joint return into serious question. Recently, several proposals have been made to redress some of these shortcomings by extending joint filing to certain nontraditional family

${ }^{264}$ See id. at 75 (arguing against Canada's alimony inclusion-deduction regime).

${ }^{265}$ See supra Part IV.E. 
arrangements. Unfortunately, these proposals do no more than chip away at the hegemony of the so-called traditional, nuclear family. They accept the privileging of the traditional family in U.S. tax law and do no more than expand the circle of privileged relationships to include those (and only those) who pattern their relationships after the traditional family form. This Article has broken sharply with these proposals by emphatically rejecting the privileging of the traditional family in our federal tax laws.

Instead, this Article has outlined a proposal for an individual tax filing system that not only recognizes that relationships can matter for tax purposes, but also embraces and accommodates the diverse relationships that individuals actually enter into-whether with spouses, partners, parents, children, cousins, aunts, uncles, friends, or neighbors. This Article also goes beyond most previous contributions to the literature that call for repeal of the joint return by actually outlining a proposal for an individual filing system. It even goes beyond the few contributions to the literature that have outlined such a proposal by sketching an inclusive individual filing system rather than focusing all of its attention on how an individual filing system should be tailored to accommodate the peculiar needs of married different-sex couples.

Nevertheless, the proposal outlined here is just that-an outline. An exhaustive proposal for an individual filing system is beyond the scope of a single article. Yet, even this partial picture gives us a sense of an individual filing system that is not nearly as complex as its opponents might fear-and, in some ways, may prove to be less complex than the joint filing regime that we currently have. ${ }^{266}$ In any event, the aim of this Article is a modest one-namely, to highlight some of the unspoken assumptions of the joint versus individual filing debate and to move that debate in a direction that is more in line with the demographic and social changes that have been unfolding in the United States for several decades. I look forward to reactions to this proposal and to suggestions for its improvement.

${ }^{266}$ See generally McMahon, supra note 2. In addition to avoiding what can be the complex question of who is "married" for federal income tax purposes, see supra note 49 and accompanying text, and achieving some simplification through coordination of the income and gift taxes, see supra note 231 , a reexamination of the many income tax provisions that implicate marital and familial status along the lines proposed by the Law Commission of Canada has the potential to result in further simplification, as provisions that do not legitimately introduce references to marital or familial status are amended or eliminated from the Internal Revenue Code. 